(C) The Author(s), 2021. Published by Cambridge University Press for the Arizona Board of Regents on behalf of the University of Arizona. This is an Open Access article, distributed under the terms of the Creative Commons Attribution licence (http://creativecommons.org/licenses/by/4.0/), which permits unrestricted re-use, distribution, and reproduction in any medium, provided the original work is properly cited.

\title{
THE ABSOLUTE CHRONOLOGY OF COLLECTIVE BURIALS FROM THE 2ND MILLENNIUM BC IN EAST CENTRAL EUROPE
}

\section{Przemysław Makarowicz ${ }^{1 *(1)} \cdot$ Tomasz Goslar $^{2,3}$ (D) Jacek Górski ${ }^{4,5} \cdot$ Halina Taras $^{6}$ •}

Anita Szczepanek ${ }^{7}$ (D) Lukasz Pospieszny $^{8,9} \cdot$ Marina O Jagodinska $^{10} \bullet$

Vasyl Ilchyshyn ${ }^{11} \cdot$ Piotr Włodarczak $^{7}$ - Anna Juras ${ }^{12} \cdot$ Maciej Chyleński $^{12}$ •

Przemysław Muzolf ${ }^{13}$ • Anna Lasota-Kuś ${ }^{7}$ - Irena Wójcik ${ }^{5}$ - Andrzej Matoga ${ }^{5}$ •

Marek Nowak $^{14}$ - Marcin M Przybyła ${ }^{15}$ - Małgorzata Marcinkowska-Swojak ${ }^{16}$ •

Marek Figlerowicz ${ }^{16} \cdot$ Ryszard Grygiel $^{17}$ • Janusz Czebreszuk ${ }^{1} \cdot$ Igor T Kochkin $^{18}$

${ }^{1}$ Faculty of Archaeology, Adam Mickiewicz University in Poznań, Uniwersytetu Poznańskiego 7, 61-614 Poznań, Poland

${ }^{2}$ Faculty of Physics, Adam Mickiewicz University in Poznań, Uniwersytetu Poznańskiego 2, 61-614 Poznań, Poland ${ }^{3}$ Poznań Radiocarbon Laboratory, Poznań Park of Science and Technology, Rubież 46, 61-612 Poznań, Poland

${ }^{4}$ Department of History and Cultural Heritage, University of Pope Jan Paweł II, Kanonicza 9, 31-002 Kraków, Poland

${ }^{5}$ Archaeological Museum in Cracow, Senacka 3, 31-002, Kraków, Poland

${ }^{6}$ Institute of Archaeology, Maria Curie-Skłodowska University, M.C.-Skłodowska Sq. 4, $20-031$ Lublin, Poland

${ }^{7}$ Institute of Archaeology and Ethnology, Polish Academy of Sciences, Sławkowska 17, 31-016 Kraków, Poland

${ }^{8}$ Institute of Archaeology and Ethnology, Polish Academy of Sciences, ul. Rubież 46, 61-612 Poznań, Poland

${ }^{9}$ Department of Anthropology and Archaeology, University of Bristol, 43 Woodland Road, Bristol BS8 1UU, United Kingdom

${ }^{10}$ Ternopil Regional Center for Protection and Research of Cultural Heritage Sites, Brodivska 44, 46020 Ternopil, Ukraine

${ }^{11}$ Protection Archaeological Service of Ukraine, Institute of Archaeology, National Academy of Sciences of Ukraine, Geroiv Stalingrada 12, 04210 Kiiv, Ukraine

${ }^{12}$ Department of Human Evolutionary Biology, Institute of Anthropology, Faculty of Biology, Adam Mickiewicz University in Poznań, Uniwersytetu Poznańskiego 6, 61-614 Poznań, Poland

${ }^{13}$ Institute of Archaeology, Rzeszów University, Moniuszki 10, 35-016 Rzeszów, Poland

${ }^{14}$ Institute of Archeology, Jagiellonian University, Collegium Minus, Gołębia 11, 31-007 Kraków, Poland

${ }^{15}$ Archaeological company “Dolmen Marcin Przybyła, Michał Podsiadło s.c.”, Serkowskiego Sq. 8/3, 30-512 Kraków, Poland

${ }^{16}$ Institute of Bioorganic Chemistry, Polish Academy of Sciences, Noskowskiego 12/14, 61-704 Poznań, Poland

${ }^{17}$ Archaeological and Ethnographical Museum in Łódź, Wolności Sq. 14, 91-415 Łódź, Poland

${ }^{18}$ Faculty of History, Politology and International Relations, Vasyl Stefanyk Precarpathian National University, Shevchenka 57, 76025 Ivano-Frankivs'k, Ukraine

\begin{abstract}
This article discusses the absolute chronology of collective burials of the Trzciniec Cultural Circle communities of the Middle Bronze Age in East Central Europe. Based on Bayesian modeling of 91 accelerator mass spectrometry radiocarbon $\left(\mathrm{AMS}{ }^{14} \mathrm{C}\right.$ ) dates from 18 cemeteries, the practice of collective burying of individuals was linked to a period of 400-640 (95.4\%) years, between 1830-1690 (95.4\%) and $1320-1160$ $(95.4 \%)$ BC. Collective burials in mounds with both cremation and inhumation rites were found earliest in the upland zone regardless of grave structure type (mounded or flat). Bayesian modeling of ${ }^{14} \mathrm{C}$ determinations suggests that this practice was being transmitted generally from the southeast to the northwest direction. Bayesian modeling of the dates from the largest cemetery in Żerniki Górne, Lesser Poland Upland, confirmed the duration of use of the necropolis as ca. 140-310 (95.4\%) years. Further results show the partial contemporaneity of burials and allow formulation of a spatial and temporal development model of the necropolis. Based on the investigation, some graves were used over just a couple of years and others over nearly 200, with up to 30 individuals found in a single grave.
\end{abstract}

KEYWORDS: AMS ${ }^{14} \mathrm{C}$ dates, Bayesian modeling, collective burials, mortuary houses, Trzciniec Cultural Circle.

\footnotetext{
*Corresponding author. Email: przemom@amu.edu.pl.
} 


\section{INTRODUCTION}

Throughout the prehistory of Europe, larger cultural changes and developments are mirrored by changing forms and meanings of burial practices. One of the major characteristics of the change taking place in the Early Bronze Age of Central Europe was the differentiation of burial rites. Already in the Final Neolithic, i.e., first half of the third millennium BC, the appearance of individual burials with the Corded Ware Culture and Bell Beakers was accompanied by the disappearance of collective burials (e.g., Czebreszuk 2008; Heyd 2013; Vander Linden 2013; Furholt 2014; Bourgeois and Kroon 2017; Włodarczak 2017). In mass burials, the use of a single structure for burying multiple individuals led to the depersonalization of grave goods, linking them to the collective of individuals buried inside. This particular phenomenon originated in Middle Neolithic communities, where "collective gifts" were the regular form of object affiliation (e.g., Whittle 1996; Cunliffe 2011; SalazarGarcía et al. 2016; Steuri et al. 2019). Contrastingly, in individual burials, the interment of personal objects became a typical constituent of the burial rite. This personalization of grave goods was tied to the increasing significance of property of the buried individuals or represented gifts for the dead from the living community, a common phenomenon in the Early Bronze Age burial rite. Although collective burials were still found among both individualized and stratified communities such as the Únětice or the Otomani-Füzesabony, such practices were not prevalent (e.g., Zich 1996; Kristiansen 1998; Harding 2000; Kadrow 2001; Thomas 2008).

In the second quarter of the 2nd millennium BC in Central-Eastern Europe the tendency to individualize death halted. Collective burials regained their popularity, especially in the area between the Oder basin to the west and the Dnieper basin to the east. This wide area can be tied to the Trzciniec Cultural Circle (henceforth TCC), a cultural entity which was developing until the end of the millennium (Figure 1; Makarowicz 2010a; Górski 2017).

The TCC was a unit of longue durée (Braudel et al. 1994), a long-term macrostructure (700 years) found across a vast area $\left(800,000 \mathrm{~km}^{2}\right)$. This cultural unit was strongly differentiated from other dominating cultural units in Central-Eastern Europe and was characterized by a relatively large degree of autonomous development (Kośko and Klochko 1998; Makarowicz 2010a).

From an epistemological point of view, the burial rite of the TCC was characterized by a great diversity of recognized forms (Makarowicz 2010a: 201-280; Górski 2017). Burials were found in separated areas, i.e., cemeteries or single graves, and rarely in settlement contexts such as re-used storage pits. From a formal standpoint, the burials of the TCC can be linked to barrow and flat cemeteries, where inhumation, cremation and biritual rites were documented.

From a quantitative standpoint the majority of the deceased were buried in mass graves, a specific form of funerary architecture and a characteristic trait of the sepulchral rites of the TCC communities. Collective burials were documented across the entire area of habitation, both in "regular" cemeteries as well as in features found on settlements. Collective graves adhering to the inhumation rite were prevalent, although variants with cremated remains were encountered as well. Partial burials and non-anatomic arrangements were well-documented together with the displacement of individual burials inside the graves (Makarowicz 2010a: 244f.).

Graves with collective burials were usually rectangular in shape with rounded or oval-like outlines and rarely trapezoid- or rhomboid-shaped cross-sections. The size of such structures was differentiated as a consequence (by design or outcome) of the number of buried individuals as well as the duration of use of the grave. Burial chambers were re-opened in 


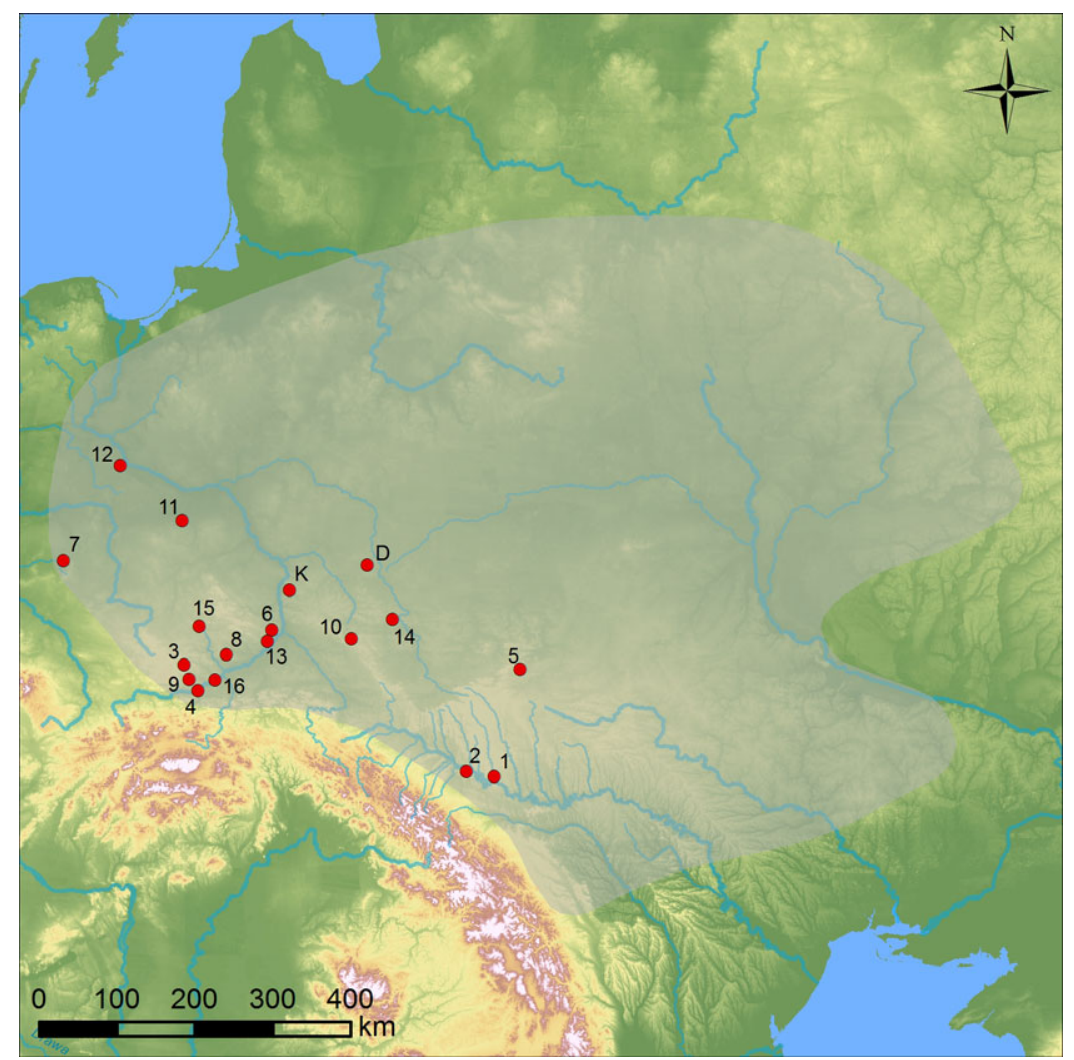

Figure 1 Trzciniec Cultural Circle cemeteries with the collective graves dated using ${ }^{14} \mathrm{C}$ method against the spatial range of the TCC (Makarowicz 2010a). Numbers of sites according to chronological order displayed in Figure 5. 1-Beremiany, 2-Bukivna, 3-Miechów, 4-Nowa Huta, 5-Kordyshiv, 6-Dacharzów, 7-Strugi, 8-Żerniki Górne, 9-Pielgrzymowice, 10-Guciów, 11-Polesie, 12-Gustorzyn, 13-Gnieszowice, 14-Brodzica, 15Bocheniec, 16-Koszyce. The sites: D-Dubeczno, and $\mathrm{K}$-Kazimierzów, represented by single ${ }^{14} \mathrm{C}$ dates, were not included in chronological ordering. Acc. to Romaniszyn et al. 2016; Makarowicz et al. 2018; Taras 1995; Górski and Makarowicz 2012; Kłosińska 1987; Ilchyshyn 2016; Górski and Tyniec 2018; Kłosińska et al. 2010; Florek and Taras 2003; Kempisty 1978; Juras et al. 2020; Górski et al. 2011; Banasiewicz-Szykuła et al. 2008; Grygiel 1987; Matoga 1985; Makarowicz 2010a, 2010b. Drawn by J. Niebieszczański.

order to bury additional individual, or more probably, a group of deceased which were buried elsewhere until excarnation (Górski, Tyniec 2018; Makarowicz 2019). The largest graves, 4-5 $\mathrm{m}$ long and 3-4 $\mathrm{m}$ wide, had an area of $15-20 \mathrm{~m}^{2}$. Stone, wood and combined architecture were encountered, often of a simple construction. The roofs were supported by four posts and walls were erected to a low height. Although the complete reconstruction of such structures was not possible due to the preservation conditions, they most likely resembled shed-like forms (Makarowicz 2010b; see also: Bátora 1999).

Barrow and flat graves were characterized by burials of 2-30 individuals and included men, women, and children, suggesting that the burial rite was rather egalitarian, which can be considered unusual for a Middle Bronze Age society. Deceased were often, but not exclusively, buried in antipodal (antithetic or inverted) arrangement, with the heads placed along the shorter sides of the burial chamber and the long bones pointing towards the center of the grave. Whenever a large number of the deceased have been identified during 

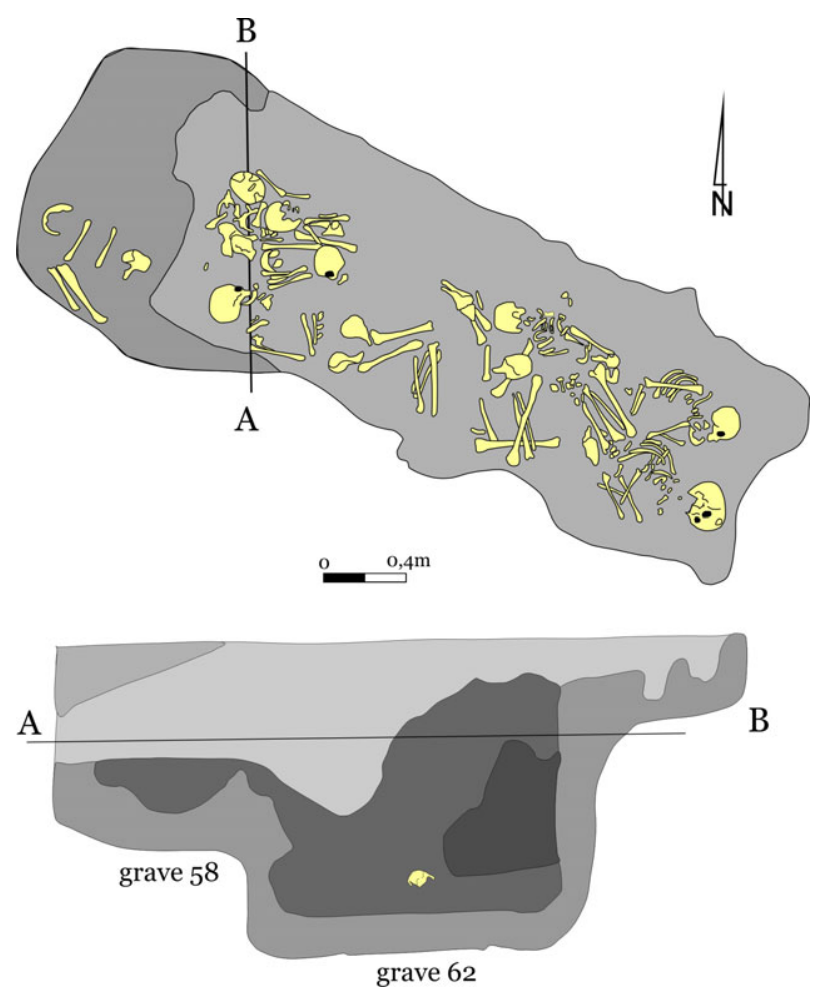

Figure 2 A typical collective burial of the Trzciniec Cultural Circle: an example from Żerniki Górne, Lesser Poland, grave 62 (Kempisty 1978). Drawn by J. Romaniszyn.

excavations, the remains have been encountered in a pile, though they did not reach the walls of the chamber. The space between the bone pile and the walls of the chamber likely would have been filled by a wooden construction, e.g., a coffin or a chest-like structure, which had since undergone mineralization (Figure 2). Collective graves were used for a long time period, which required the displacement of the previously buried individuals with the final burial often positioned in the center of the grave (Makarowicz 2010a, 2010b; Szczepanek 2013).

The aim of this paper is to examine the absolute chronology of collective burials of the TCC by means of AMS ${ }^{14} \mathrm{C}$ dating and to investigate the spatial development of this form of burial rite. Further analyses are aimed at formulating a historical understanding of selected cemeteries and, more specifically, selected collective graves. The Bayesian-modeled chronology of the largest cemetery with collective graves in Żerniki Górne, Lesser Poland, was implemented in order to define the sequence of burial construction and use. A selected case study of a collective burial with a particularly large number of ${ }^{14} \mathrm{C}$ dates is investigated using Bayesian modeling to identify the overall duration of use of individual mass graves and timespan of the burial rite.

\section{MATERIALS AND METHODS}

The dating program targeted 18 necropolises with collective burials located in the Upper Vistula and Middle Warta basins in Poland and in the Upper Dniester basin in Ukraine (Figure 1). The sample comprises of both barrow and flat cemeteries. In total, 91 
individuals representing 42 mass burials were analyzed. The biological determination of sex was possible for 62 individuals and identified 25 females and 37 males. Age-determination was possible for 86 deceased and included 2 adolescents and 14 children. In the remaining cases, the state of preservation of biological traits did not allow a more detailed identification of sex or age (Table 1). Twenty-four individuals were found in graves covered with mounds; the remainder were recognized in flat graves. The majority of grave constructions were comprised of stone components, i.e., slabs and erratic boulders, while the wooden constituents were coffin- or chest-like forms comprised of planks or logs. Combinations of both were also noticed, often reinforced with clay or sediment. The ${ }^{14} \mathrm{C}$ samples were extracted from long bones or skulls. In the case of the sites Bukivna and Gnieszowice, all sampled bones were cremated in situ, due to the burning down of the wooden so-called mortuary houses during the burial event (Makarowicz et al. 2018).

Collagen from the non-cremated bones was extracted using the Longin method (1971) supplemented by stages of removing humic substance in a $\mathrm{NaOH}$ solution and ultrafiltration of the extract (Bronk Ramsey et al. 2004; Brock et al. 2010). The measured collagen extraction yield and the atomic ratio of $\mathrm{C} / \mathrm{N}$ in collagen (Table 1), indicates good purity of the extracts (van Klinken et al. 1999). In relation to cremated bones the Lanting et al. (2001) procedure was applied, which allows extraction of carbon from structural carbonate (apatite) fraction. Portions of $\mathrm{CO}_{2}$ resulting from the combustion of collagen or decomposition of structural carbonate were graphitized with hydrogen $\left(\mathrm{H}_{2}\right)$, and isotopic ratios ${ }^{14} \mathrm{C} /{ }^{12} \mathrm{C}$ and ${ }^{13} \mathrm{C} /{ }^{12} \mathrm{C}$ in the acquired graphite were measured using the "Compact Carbon AMS" spectrometer (Goslar et al. 2004). The stable isotopic composition of collagens $\left(\delta^{15} \mathrm{~N}\right.$ and $\left.\delta^{13} \mathrm{C}\right)$ was analyzed with IRMS, at the Goethe University in Frankfurt.

${ }^{14} \mathrm{C}$ ages of the samples (Stuiver and Polach 1977$)$ are shown in Table $1\left({ }^{14} \mathrm{C} \mathrm{BP}\right)$. The clear differences in the conventional ${ }^{14} \mathrm{C}$ ages of bone material from the analyzed cemeteries (e.g., 3420-3500 BP from Beremiany and 3005-3135 BP from Bocheniec) suggest that the ritual of collective burials was practiced in particular areas in different time periods. However, it must be considered that the discrepancies in the measured ${ }^{14} \mathrm{C}$ age could be a direct outcome of the diet of the dated individuals. Should the past communities have relied on the consumption of aquatic products, the results of the ${ }^{14} \mathrm{C}$ dating would be affected by the "reservoir effect" (e.g., Cook et al. 2001; Olsen et al. 2010).

In general, aquatic organisms have higher ${ }^{15} \mathrm{~N} /{ }^{14} \mathrm{~N}$ ratios value than terrestrial organisms. These higher values are then reflected in the measured $\delta^{15} \mathrm{~N}$ values of all organisms who consume them, including humans with aquatic-rich diets. Comparative studies of individuals from different parts of Europe (Goslar et al. 2017) have shown that the $\delta^{15} \mathrm{~N}$ values of human bone collagen of individuals relying solely on terrestrial food sources were also subject to variation. In Giecz, ca. $100 \mathrm{~km} \mathrm{NW}$ of the analyzed cemetery in Strugi (Figure 1), the $\delta^{15} \mathrm{~N}$ values (Reitsema et al. 2010) were within 8 and $10.5 \%$ range, while for the Yampil barrow complex in Ukraine (ca. $150 \mathrm{~km}$ SE of the site in Beremiany; Figure 1) the $\delta{ }^{15} \mathrm{~N}$ values fell within the $8-12 \%$ range. Considering this background, intervals of $\delta^{15} \mathrm{~N}$ values of the present study (Figure 3) indicate that aquatic food sources were insignificant at the examined sites as well. It would also be expected that a diet rich in fish would result in a positive correlation between the $\delta^{15} \mathrm{~N}$ values (increased due to the aquatic diet) and the ${ }^{14} \mathrm{C}$ age (appearing "older" due to the reservoir effect). In terms of the analyzed samples, such a correlation was not observed (either for the whole set of analyzed samples $\left[r^{2}=0.016\right]$ or for the subsets representing individual sites; Figure 3), additionally 
Table $1{ }^{14} \mathrm{C}$ ages of samples collected from the mass graves described in the text. Values of $\%$ coll/C/ $\mathrm{N}_{\mathrm{at}}$ represent collagen extraction yields and atomic $\mathrm{C} / \mathrm{N}$ ratios measured in collagen

\begin{tabular}{|c|c|c|c|c|c|c|c|c|c|}
\hline Site & Barrow/feature & Mat. & Sex & Age at death (yr) & $\begin{array}{c}\text { Lab no. } \\
\text { Poz- }\end{array}$ & ${ }^{14} \mathrm{C} B P$ & $\%$ coll $/ \mathrm{C} / \mathrm{N}_{\mathrm{at}}$ & $\delta^{15} \mathrm{~N} \%$ & $\delta^{13} \mathrm{C} \%$ \\
\hline Beremiany & $-/ 1$ & b. & $\mathrm{F}$ & $22-25$ & 61777 & $3500 \pm 30$ & $6.3 / 3.44$ & 11.3 & -20.7 \\
\hline Beremiany & $-/ 1$ & b. & M & $22-25$ & 76313 & $3420 \pm 35$ & $3.4 / 3.33$ & 10.4 & -20.1 \\
\hline Bocheniec & $-/ 118$ & b. & $\mathrm{F}$ & $20-30$ & 89338 & $3135 \pm 30$ & $6.7 / 3.15$ & 11.2 & -20.1 \\
\hline Bocheniec & $-/ 118$ & b. & $?$ & $40-50$ & 89342 & $3050 \pm 35$ & $8.2 / 3.21$ & 10.5 & -12.8 \\
\hline Bocheniec & $-/ 118$ & b. & M & $40-50$ & 89339 & $3015 \pm 30$ & $6.6 / 3.18$ & 9.7 & -15.6 \\
\hline Bocheniec & $-/ 118$ & b. & $\mathrm{F}$ & $20-30$ & 89341 & $3010 \pm 35$ & $5.7 / 3.16$ & 10.5 & -15.5 \\
\hline Bocheniec & $-/ 118$ & b. & $\mathrm{F}$ & $40-50$ & 89343 & $3005 \pm 30$ & $5.8 / 3.09$ & 11.9 & -14.2 \\
\hline Brodzica & $-/ 34$ & b. & $?$ & $0-7$ & 107536 & $3125 \pm 30$ & 7.0/3.09 & 6.7 & -15.8 \\
\hline Brodzica & $-/ 34$ & b. & M? & $20-30$ & 83832 & $3145 \pm 30$ & $11.7 / 3.20$ & 10.7 & -16.7 \\
\hline Bukivna & $6 / 2 \mathrm{~A}$ & b.b. & $\mathrm{F}$ & $20-35$ & 73405 & $3440 \pm 40$ & Carbonate & - & - \\
\hline Bukivna & $6 / 2 \mathrm{~A}$ & b.b. & M & $20-35$ & 73406 & $3355 \pm 30$ & Carbonate & - & - \\
\hline Dacharzów & $1 / 1 \mathrm{~A}$ & b. & $\mathrm{F}$ & $20-30$ & 89345 & $3275 \pm 35$ & $2.2 / 3.18$ & 11.9 & -19.9 \\
\hline Dacharzów & $-/ 10$ & b. & $?$ & $0-1$ & 83836 & $3135 \pm 35$ & $9.6 / 3.12$ & 7.3 & -16.4 \\
\hline Dacharzów & $-/ 10$ & b. & $?$ & $7-14$ & 83835 & $3115 \pm 30$ & $12.3 / 3.19$ & 8.3 & -13.5 \\
\hline Dubeczno & $1 / 1$ & b. & M & $30-40$ & 107547 & $3340 \pm 35$ & $5.2 / 3.25$ & 9.6 & -20.8 \\
\hline Gnieszowice & $-/ 1$ & b.b. & M & $40-50$ & 89747 & $3235 \pm 30$ & Carbonate & - & - \\
\hline Gnieszowice & $-/ 1$ & b.b. & $\mathrm{F}$ & $20-30$ & 89746 & $3215 \pm 30$ & Carbonate & - & - \\
\hline Gnieszowice & $-/ 1$ & b.b. & $?$ & $7-14$ & 89748 & $3170 \pm 30$ & Carbonate & - & - \\
\hline Gnieszowice & $-/ 1$ & b.b. & M? & $40-50$ & 89749 & $3145 \pm 30$ & Carbonate & - & - \\
\hline Guciów & $13 / 1$ & b. & $\mathrm{M}$ & $30-40$ & 107320 & $3245 \pm 30$ & $15.0 / 3.20$ & 10.0 & -20.3 \\
\hline Guciów & $13 / 1$ & b. & $?$ & $8-9$ & 107319 & $3205 \pm 30$ & $11.7 / 3.22$ & 11.0 & -19.8 \\
\hline Guciów & $13 / 1$ & b. & $\mathrm{F}$ & $20-30$ & 107323 & $3180 \pm 40$ & $16.7 / 3.19$ & 10.4 & -20.0 \\
\hline Gustorzyn & $-/ 5$ & b. & $\mathrm{F}$ & $20-30$ & 101466 & $3185 \pm 35$ & $1.2 / 3.21$ & 10.8 & -20.3 \\
\hline Gustorzyn & $-/ 5$ & b. & $\mathrm{F}$ & $20-30$ & 101465 & $3160 \pm 35$ & $8.0 / 3.22$ & 9.7 & -19.8 \\
\hline Gustorzyn & $-/ 5$ & b. & M & $20-30$ & 101025 & $3045 \pm 35$ & $4.0 / 3.21$ & 9.8 & -20.0 \\
\hline Gustorzyn & $-/ 4$ & b. & M & $40-50$ & 101065 & $3030 \pm 35$ & $5.3 / 3.22$ & 10.1 & -19.9 \\
\hline Kazimierzów & $1 / 1$ & b. & $\mathrm{M} ?$ & $30-40$ & 89344 & $3105 \pm 35$ & $9.7 / 3.16$ & 11.1 & -20.6 \\
\hline Kordyshiv & $3 / 1$ & b. & - & - & 83755 & $3325 \pm 35$ & $6.8 / 3.26$ & 7.8 & -19.9 \\
\hline Kordyshiv & $3 / 1$ & b. & - & - & 83756 & $3315 \pm 35$ & $6.5 / 3.24$ & 7.8 & -20.1 \\
\hline Kordyshiv & $3 / 1$ & b. & - & - & 89337 & $3265 \pm 30$ & $4.3 / 3.12$ & 11.3 & -15.7 \\
\hline
\end{tabular}




\begin{tabular}{|c|c|c|c|c|c|c|c|c|c|}
\hline Site & Barrow/feature & Mat. & Sex & Age at death (yr) & $\begin{array}{c}\text { Lab no. } \\
\text { Poz- }\end{array}$ & ${ }^{14} \mathrm{C} \mathrm{BP}$ & $\%$ coll/ $\mathrm{C} / \mathrm{N}_{\mathrm{at}}$ & $\delta^{15} \mathrm{~N} \% 0$ & $\delta^{13} \mathrm{C} \%$ \\
\hline Kordyshiv & $3 / 9$ & b. & - & - & 83757 & $3155 \pm 30$ & $5.0 / 3.28$ & 8.1 & -17.8 \\
\hline Kordyshiv & $3 / 7$ & b. & - & - & 89335 & $3150 \pm 35$ & $14.3 / 3.08$ & 11.3 & -15.7 \\
\hline Koszyce & $-/ 119$ & b. & $\mathrm{F}$ & $20-30$ & 24809 & $3105 \pm 35$ & $3.8 / 3.19$ & 9.2 & -17.3 \\
\hline Koszyce & $-/ 119$ & b. & $\mathrm{F}$ & $20-30$ & 83763 & $3075 \pm 35$ & $1.4 / 3.25$ & 8.0 & -17.5 \\
\hline Koszyce & $-/ 235$ & b. & $\mathrm{F}$ & $30-40$ & 83759 & $3100 \pm 30$ & $2.6 / 3.25$ & 7.8 & -13.6 \\
\hline Koszyce & $-/ 235$ & b. & M & $40-50$ & 83760 & $3065 \pm 30$ & $8.2 / 3.26$ & 8.3 & -16.6 \\
\hline Koszyce & $-/ 235$ & b. & $\mathrm{F}$ & $40-50$ & 24851 & $3020 \pm 30$ & $1.1 / 3.16$ & 9.4 & -12.5 \\
\hline Miechów & $-/ 173$ & b. & M & $35-40$ & 88768 & $3380 \pm 35$ & $12.6 / 3.17$ & 10.4 & -20.2 \\
\hline Miechów & $-/ 173$ & b. & $?$ & $9-11$ & 88769 & $3370 \pm 35$ & $12.1 / 3.18$ & 9.3 & -20.3 \\
\hline Miechów & $-/ 1826$ & b. & $\mathrm{F}$ & $30-35$ & 88801 & $3215 \pm 35$ & $2.5 / 3.17$ & 7.8 & -20.8 \\
\hline Miechów & $-/ 1826$ & b. & $?$ & $12-13$ & 88802 & $3200 \pm 30$ & $2.3 / 3.18$ & 9.3 & -20.8 \\
\hline Miechów & $-/ 3576$ & b. & $?$ & $15-17$ & 102806 & $3195 \pm 30$ & $8.0 / 3.18$ & 9.5 & -20.1 \\
\hline Nowa Huta & $-/ 108$ & b. & $?$ & $10-14$ & 83829 & $3370 \pm 35$ & $12.2 / 3.15$ & 7.9 & -20.4 \\
\hline Nowa Huta & $-/ 108$ & b. & $\mathrm{M}$ & $30-40$ & 83830 & $3370 \pm 30$ & $0.5 / 3.19$ & 7.8 & -20.3 \\
\hline Nowa Huta & $-/ 108$ & b. & $?$ & $7-14$ & 24810 & $3295 \pm 35$ & $2.9 / 3.20$ & 9.4 & -20.6 \\
\hline Pielgrzymowice & $-/ 669$ & b. & M & $30-40$ & 107544 & $3180 \pm 35$ & $2.8 / 3.20$ & 10.8 & -17.2 \\
\hline Pielgrzymowice & $-/ 669$ & b. & $\mathrm{F}$ & $50-55$ & 104943 & $3135 \pm 30$ & $3.7 / 3.22$ & 11.2 & -18.7 \\
\hline Pielgrzymowice & $-/ 669$ & b. & M? & $30-40$ & 101474 & $3095 \pm 35$ & $9.4 / 3.19$ & 11.2 & -17.2 \\
\hline Pielgrzymowice & $-/ 669$ & b. & $\mathrm{M} ?$ & $40-50$ & 101473 & $3075 \pm 35$ & $6.9 / 3.18$ & 11.5 & -17.0 \\
\hline Pielgrzymowice & $-/ 669$ & b. & $\mathrm{M}$ & $40-50$ & 104944 & $3035 \pm 35$ & $7.4 / 3.19$ & 10.7 & -16.5 \\
\hline Pielgrzymowice & $-/ 669$ & b. & $\mathrm{M}$ & $30-40$ & 101475 & $3030 \pm 35$ & $6.7 / 3.19$ & 11.4 & -17.2 \\
\hline Pielgrzymowice & $-/ 748$ & b. & $\mathrm{F}$ & $40-50$ & 104940 & $3320 \pm 35$ & $7.9 / 3.24$ & 8.7 & -21.1 \\
\hline Pielgrzymowice & $-/ 748$ & b. & $\mathrm{M}$ & $50-60$ & 107546 & $3130 \pm 35$ & $2.8 / 3.24$ & 10.3 & -16.3 \\
\hline Pielgrzymowice & $-/ 631$ & b. & $\mathrm{M}$ & $40-50$ & 104939 & $3200 \pm 35$ & $10.0 / 3.24$ & 9.8 & -19.9 \\
\hline Polesie & $1 / 1182$ & b. & $?$ & $30-40$ & 24716 & $3255 \pm 35$ & $2.0 / 3.25$ & 9.3 & -21.1 \\
\hline Polesie & $1 / 1182$ & b. & $\mathrm{F}$ & $30-40$ & 24714 & $3175 \pm 35$ & $2.0 / 3.22$ & 8.4 & -21.1 \\
\hline Polesie & $1 / 1182$ & b. & $\mathrm{F} ?$ & $30-50$ & 24717 & $3175 \pm 35$ & $0.6 / 3.15$ & 8.4 & -21.0 \\
\hline Polesie & $1 / 1182$ & b. & $\mathrm{M}$ & $30-45$ & 24715 & $3170 \pm 35$ & $3.2 / 3.23$ & 9.1 & -20.9 \\
\hline Polesie & $1 / 1182$ & b. & $?$ & $6-7$ & 24718 & $3150 \pm 40$ & $2.8 / 3.18$ & 8.4 & -21.1 \\
\hline Polesie & $1 / 1182$ & b.b. & $?$ & $30-40$ & 24916 & $3060 \pm 35$ & Carbonate & - & - \\
\hline
\end{tabular}




\begin{tabular}{|c|c|c|c|c|c|c|c|c|c|}
\hline Site & Barrow/feature & Mat. & Sex & Age at death (yr) & $\begin{array}{c}\text { Lab no. } \\
\text { Poz- }\end{array}$ & ${ }^{14} \mathrm{C} \mathrm{BP}$ & $\%$ coll $/ \mathrm{C} / \mathrm{N}_{\mathrm{at}}$ & $\delta^{15} \mathrm{~N} \%$ & $\delta^{13} \mathrm{C} \%$ \\
\hline Polesie & $1 / 1182$ & b.b. & $\mathrm{M}$ & $30-40$ & 24843 & $3010 \pm 40$ & Carbonate & - & - \\
\hline Strugi & $2 / 1$ & b. & M & $30-40$ & 94987 & $3295 \pm 35$ & $8.6 / 3.23$ & 8.8 & -21.0 \\
\hline Strugi & $2 / 1$ & b. & $\mathrm{M}$ & $30-40$ & 94988 & $3285 \pm 35$ & $9.5 / 3.22$ & 8.8 & -20.6 \\
\hline Strugi & $2 / 1$ & b. & M & $30-40$ & 104935 & $3280 \pm 35$ & $4.3 / 2.98$ & 8.3 & -20.1 \\
\hline Strugi & $2 / 1$ & b. & M & $30-40$ & 77351 & $3280 \pm 35$ & $8.1 / 3.25$ & - & - \\
\hline Żerniki Górne & $-/ 86$ & b. & $?$ & $30-40$ & 107537 & $3315 \pm 35$ & $6.3 / 3.22$ & 8.8 & -20.0 \\
\hline Żerniki Górne & $-/ 69$ & b. & $\mathrm{F}$ & $20-30$ & 93456 & $3295 \pm 35$ & $11.0 / 3.18$ & 9.9 & -20.0 \\
\hline Żerniki Górne & $-/ 69$ & b. & $\mathrm{F}$ & $30-40$ & 93455 & $3255 \pm 35$ & $13.8 / 3.15$ & 9.9 & -19.9 \\
\hline Żerniki Górne & $-/ 69$ & b. & M & $40-50$ & 107541 & $3255 \pm 35$ & $7.3 / 3.22$ & 9.4 & -19.9 \\
\hline Żerniki Górne & $-/ 69$ & b. & $\mathrm{F}$ & $20-30$ & 107545 & $3255 \pm 35$ & $7.9 / 3.20$ & 10.9 & -19.9 \\
\hline Żerniki Górne & $-/ 69$ & b. & $?$ & $6-7$ & 107542 & $3195 \pm 30$ & $9.4 / 3.21$ & 9.3 & -19.9 \\
\hline Żerniki Górne & $-/ 62$ & b. & $?$ & $30-40$ & 93115 & $3250 \pm 35$ & $10.0 / 3.22$ & 9.2 & -19.8 \\
\hline Żerniki Górne & $-/ 62$ & b. & $\mathrm{F}$ & $20-30$ & 93454 & $3235 \pm 35$ & $8.8 / 3.22$ & 9.8 & -19.9 \\
\hline Żerniki Górne & $-/ 62$ & b. & $\mathrm{F}$ & $20-30$ & 104933 & $3230 \pm 30$ & $7.8 / 3.21$ & 9.8 & -20.1 \\
\hline Żerniki Górne & $-/ 62$ & b. & $?$ & $6-7$ & 104812 & $3220 \pm 35$ & $7.9 / 3.21$ & 8.9 & -20.1 \\
\hline Żerniki Górne & $-/ 62$ & b. & M & $40-50$ & 104932 & $3215 \pm 35$ & $9.8 / 3.24$ & 9.3 & -20.0 \\
\hline Żerniki Górne & $-/ 62$ & b. & $?$ & $6-7$ & 101468 & $3170 \pm 35$ & $8.0 / 3.17$ & 10.2 & -20.1 \\
\hline Żerniki Górne & $-/ 71$ & b. & $\mathrm{M}$ & $40-50$ & 93457 & $3180 \pm 35$ & $10.3 / 3.17$ & 9.7 & -19.8 \\
\hline Żerniki Górne & $-/ 72$ & b. & $?$ & $20-50$ & 115529 & $3135 \pm 30$ & $6.3 / 3.21$ & - & - \\
\hline Żerniki Górne & $-/ 73$ & b. & M? & $18-20$ & 93458 & $3220 \pm 35$ & $14.0 / 3.17$ & 9.1 & -19.9 \\
\hline Żerniki Górne & $-/ 10$ & b. & $\mathrm{F}$ & $20-30$ & 107538 & $3275 \pm 35$ & $4.3 / 3.23$ & 9.4 & -20.3 \\
\hline Żerniki Górne & $-/ 10$ & b. & $\mathrm{F}$ & $40-50$ & 107539 & $3220 \pm 35$ & $9.5 / 3.24$ & 10.3 & -20.2 \\
\hline Żerniki Górne & $-/ 10$ & b. & M & $40-50$ & 92372 & $3205 \pm 35$ & $4.7 / 3.22$ & 9.4 & -20.2 \\
\hline Żerniki Górne & $-/ 12$ & b. & M & $20-30$ & 92373 & $3140 \pm 30$ & $9.8 / 3.22$ & 9.8 & -20.2 \\
\hline Żerniki Górne & $-/ 98$ & b. & $?$ & $16-18$ & 93459 & $3120 \pm 30$ & $6.5 / 3.20$ & 9.9 & -19.9 \\
\hline Żerniki Górne & $-/ 99$ & b. & M & $40-50$ & 92374 & $3110 \pm 35$ & $10.7 / 3.17$ & 10.2 & -20.6 \\
\hline Żerniki Górne & $-/ 99$ & b. & $\mathrm{M}$ & $50-55$ & 92375 & $3055 \pm 30$ & $7.0 / 3.25$ & 10.0 & -20.1 \\
\hline Żerniki Górne & $-/ 3$ & b. & $?$ & $20-50$ & 92369 & $3095 \pm 30$ & $3.4 / 3.22$ & 10.8 & -19.7 \\
\hline Żerniki Górne & $-/ 54$ & b. & M & $50-60$ & 104934 & $3075 \pm 35$ & $8.0 / 3.20$ & 10.0 & -17.1 \\
\hline Żerniki Górne & -15 & b. & $\mathrm{M}$ & $40-50$ & 92370 & $3065 \pm 30$ & $2.0 / 3.27$ & 10.7 & -19.1 \\
\hline Żerniki Górne & $-/ 117$ & b. & $?$ & $18-20$ & 92368 & $2985 \pm 35$ & $1.7 / 3.21$ & 7.6 & -21.9 \\
\hline
\end{tabular}




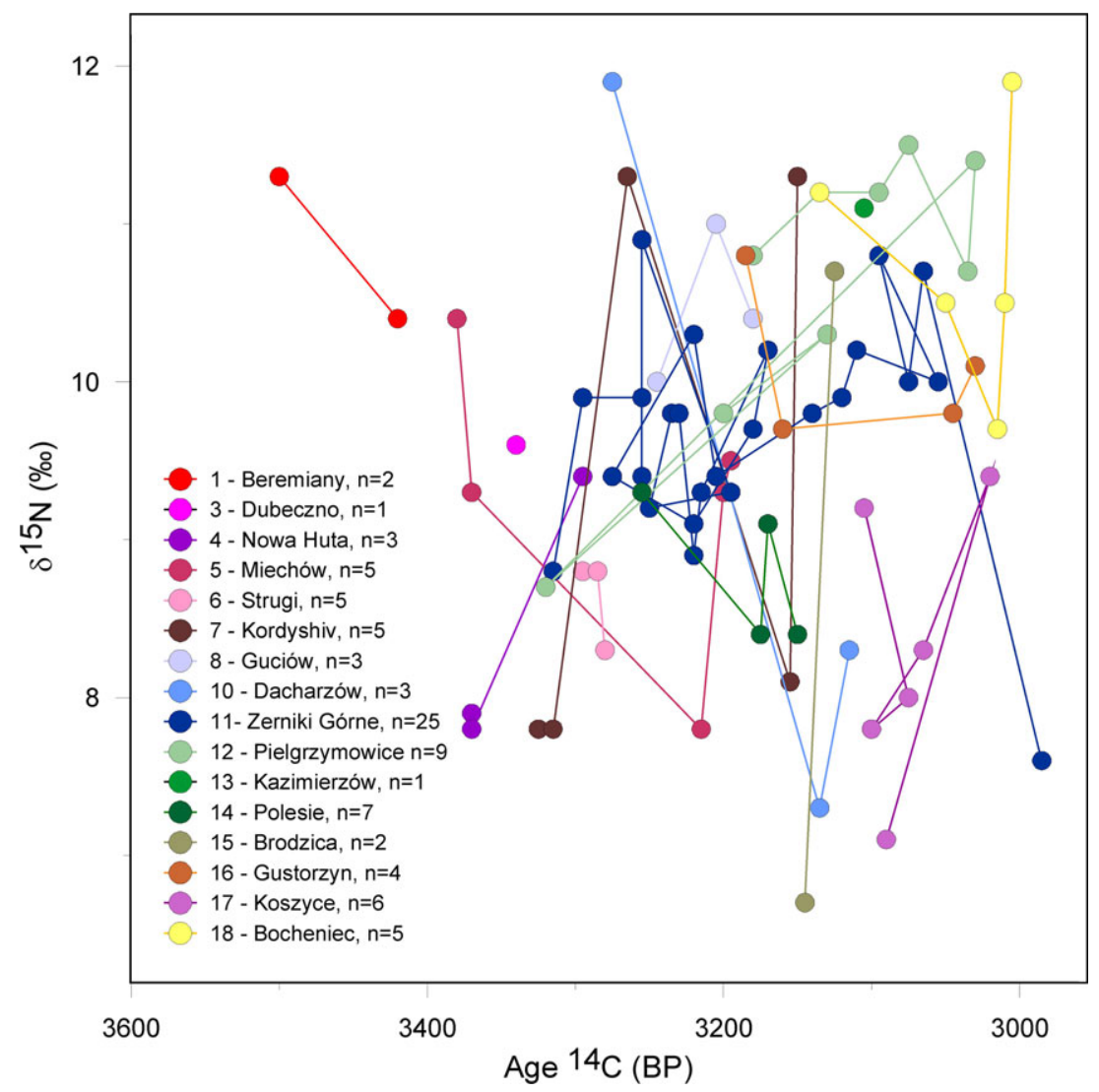

Figure $3 \quad \delta^{15} \mathrm{~N}$ values and ${ }^{14} \mathrm{C}$ ages of bones analyzed in this study.

supporting our argument that the differences of the TCC dates from different areas, were not caused by the reservoir effects.

On the other hand, the rather wide range of $\delta^{13} \mathrm{C}$ values measured in our samples, could be fully interpreted in terms of mixing C4- and C3-photosynthesizing terrestrial plants in human diet. However, explanation of this phenomenon is beyond topic of this paper and will be discussed in a separate publication (Pospieszny et al., in press).

As documented e.g., by Snoeck et al. (2014), ${ }^{14} \mathrm{C}$ ages determined using structural carbonate (apatite), could potentially be affected due to exchange with the carbon derived from fuel during the cremation process. Significant effect, however, may occur only when the fuel contained "old wood" (e.g., descending from inner parts of big wooden timbers) or coal, a situation that was rarely the case. Exchange of carbon affects also $\delta^{13} \mathrm{C}$ values of the apatite. In our study, $\delta^{13} \mathrm{Cs}$ of cremated bones were measured with the AMS spectrometer only, so accuracy of these measurements is arguable. On the one hand, the high values obtained from two dated bone samples from Bukivna and two bones from Polesie $\left(\delta^{13} \mathrm{C}_{\mathrm{AMS}}\right.$ between $-20 \%$ and $-16 \%$ ), suggest that carbon exchange with fuel (having $\delta^{13} \mathrm{C}$ around $-25 \%$ ) was insignificant. On the other hand, the $\delta^{13} \mathrm{C}_{\mathrm{AMS}}$ measured in four bones from Gnieszowice (between $-29 \%$ and $-26 \%$ ) indicate strong exchange, so ${ }^{14} \mathrm{C}$ ages from this site must be interpreted with caution. After careful examination we decided that 
questionable credibility of dates from this single site (which appears to be one of the youngest sites studied, cf. Figure 5), does not affect our conclusions in any degree.

\section{DISCUSSION AND RESULTS}

\section{Absolute Chronology of the TCC Collective Grave Cemeteries}

${ }^{14} \mathrm{C}$ ages were calibrated against the IntCal13 curve (Reimer et al. 2013) and underwent Bayesian analysis performed using OxCal v4.2.3 (Bronk Ramsey 1995, 2009; Bronk Ramsey and Lee 2013). The ${ }^{14} \mathrm{C}$ calibration included the limited carbon renewal effect whereby the level of ${ }^{14} \mathrm{C}$ in the collagen of a living organism reflects the average concentration of ${ }^{14} \mathrm{C}$ in the atmosphere over the preceding time period.

According to Geyh (2001), this effect could be corrected for by means of a correction term dependent on the age at death of the individual. In reference to Geyh's study, Barta and Štolc (2007) introduced a concept of human bone collagen offset (HBCO) depending on skeletal age and proposed implementing HBCOs by means of the Delta_R command available in many ${ }^{14} \mathrm{C}$ calibration tools. However, the Delta_R, widely applied when correcting ${ }^{14} \mathrm{C}$ dates for the reservoir effect, concerns the domain of ${ }^{14} \mathrm{C}$ time scale. Conversely, the fact that the collagen in a bone contains carbon derived from the environment over considerable period of time preceding the moment of organism's death should be corrected for in the domain of calendar time. In the present work, we used the age-dependent correction terms to Shift probability distributions of calibrated dates, admitting that the magnitude of the shift, unknown exactly, has its own probability distribution. Practically, for each sample we used one of a few normal distributions, depending on the class of the age at death (Adultus, Maturus, etc., see Figures 4a and 4b). For bones from Kordyshiv, where the skeletal ages haven't been determined, we assumed the Shift to be uniformly distributed between 0 and 30 years. One must point out that the corrections as described above are rather small, and in terms of age differences measuring several centuries (e.g., see below for the dates from different cemeteries or dates from different graves) have no major impact on the analysis.

The Bayesian modeling allowed the grouping of dates from particular cemeteries into separate phases without assuming any relations between the phases (Figures $4 \mathrm{a}$ and $4 \mathrm{~b}$ ).

Boundaries of particular phases (estimating the time frames of burials in individual cemeteries) show (Figure 5, upper) that the analyzed necropolises represent different chronological stages.

The temporal relation between burial grounds was quantitatively represented by a probability matrix ("Order" function). In this matrix every element " $\mathrm{P}\left(\mathrm{t}_{1}<\mathrm{t}_{2}\right)$ " (Figure 5, lower part) shows the probability that the cemetery in site " 1 " began to be used earlier than the cemetery in site " 2 ".

The Bayesian modeling of the ${ }^{14} \mathrm{C}$-dates suggests that collective burials of the TCC had a long chronology, generally falling between 1830-1690 (95.4\%) and 1320-1160 (95.4\%) BC. From an archaeological standpoint this represents the entire duration of the cultural unit, i.e., the late Early and Middle Bronze Age. Successful transmission of the collective burial practice for ca. $400-650(95.4 \%)$ or $430-560(68.2 \%)$ years (approximately max. 16-25 generations) allows it to be considered a long-term custom, possibly linked to identity-formation of the TCC communities. The duration of cemeteries with collective burials was diverse, sometimes exceeding 200 or more years (for the Spans, see Figures $4 \mathrm{a}$ and $4 \mathrm{~b}$ ). 


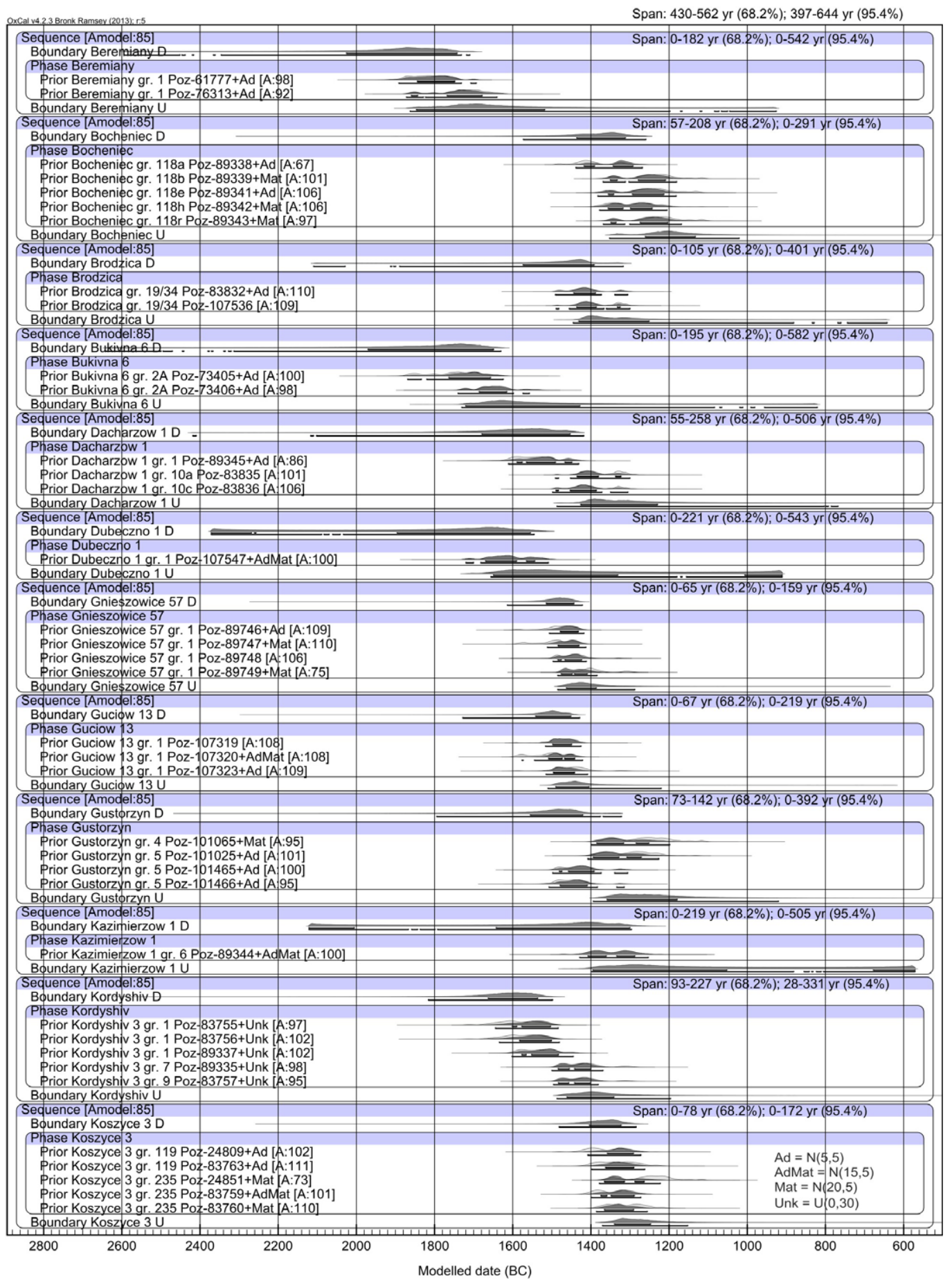

Figure $4 \mathrm{a}$ Bayesian chronological model of ${ }^{14} \mathrm{C}$ dates of bones from the necropolises investigated in this study. Distributions of Shifts applied to different classes of skeletal age (for details, see the text) are specified in the right-lower corner of the diagram. Spans of modeled dates, as calculated for each individual cemetery and for the whole set of the TCC sites, are also displayed. Ad=Adultus, AdMat=Adultus/Maturus, Mat=Maturus, Unk=Unknown, MatSen=Maturus/Senilis, Ad_Mat=Adultus-Maturus. 


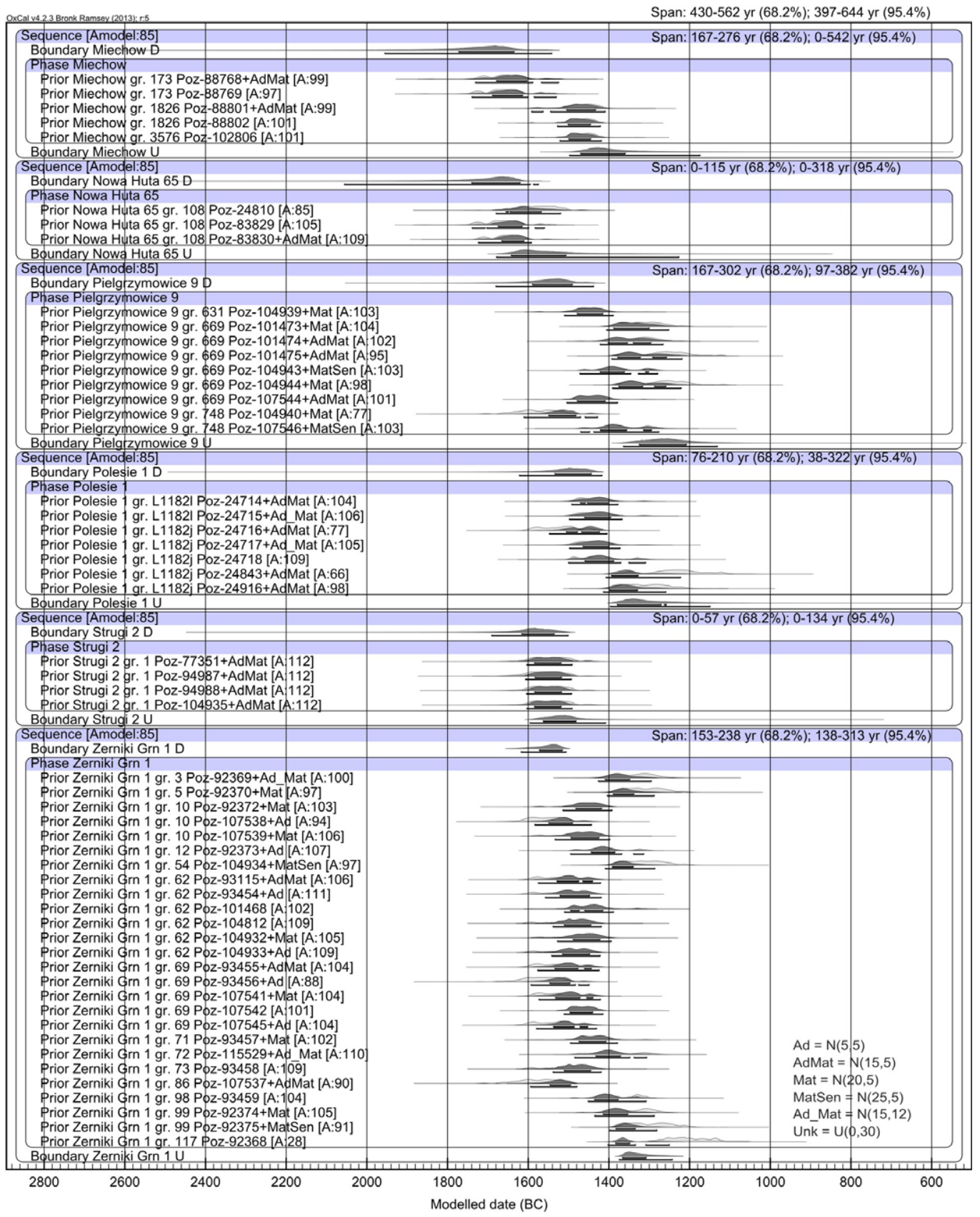

Figure $4 \mathrm{~b}$ Bayesian chronological model of ${ }^{14} \mathrm{C}$ dates of bones from the necropolises investigated in this study (continued).

The spatial distribution of ${ }^{14} \mathrm{C}$ dates from collective burials indicates that the structures appeared earliest in the Podolian Upland around the Upper Dniester (Beremiany and Bukivna then Kordishiv), slightly later in the Lesser Poland Upland (Miechów, Nowa Huta-Mogiła), Lublin Polesie (Dubeczno) and Sandomierz Upland (Dacharzów), and 


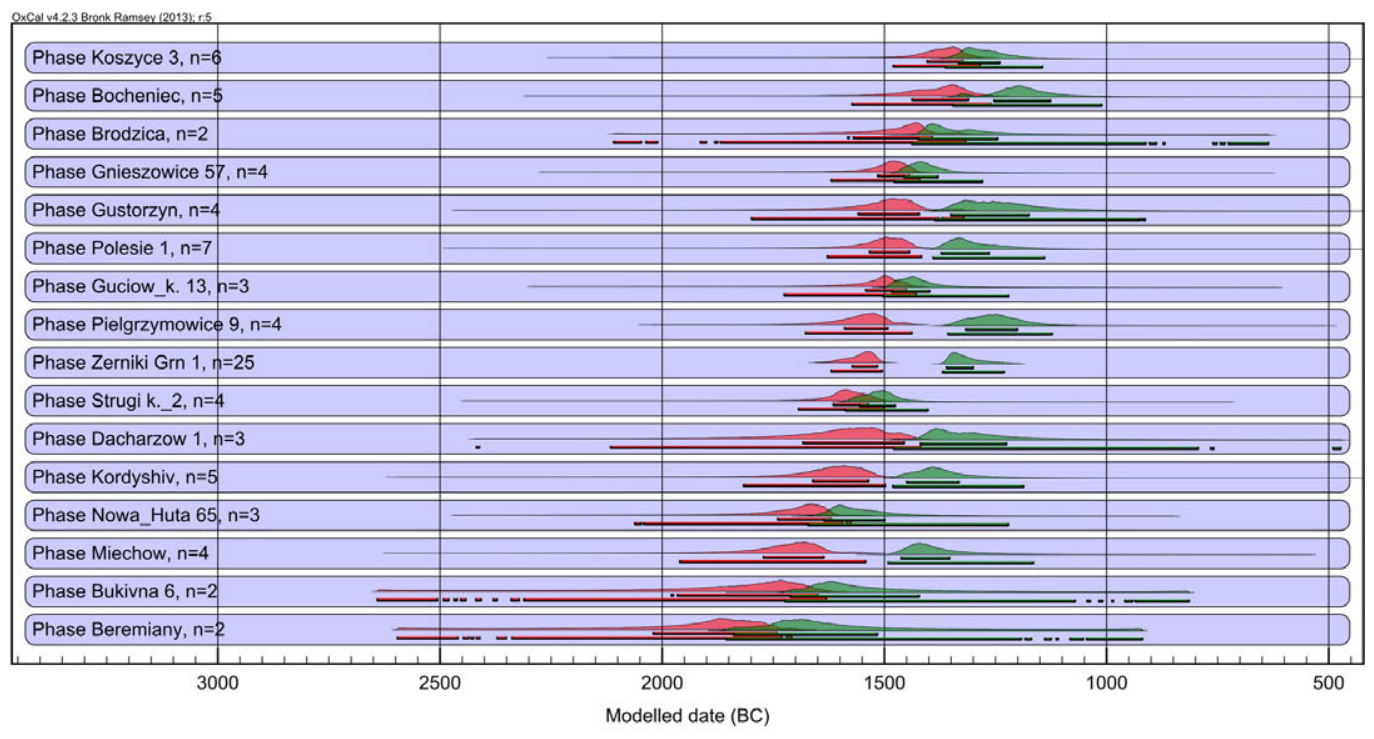

Phase Beremiany, $n=2$

Phase Bukivna 6, $\mathrm{n}=2$

Phase Miechow, $n=5$

Phase Nowa_Huta $65, n=3$

Phase Kordyshiv, $n=5$

Phase Dacharzow 1, n=3

Phase Strugi k._2, n=4

Phase Zerniki Grn 1, n=26

Phase Pielgrzymowice $9, n=9$

Phase Guciow_k. 13, n=3

Phase Polesie 1, n=7

Phase Gustorzyn, $n=4$

Phase Gnieszowice $57, \mathrm{n}=4$

Phase Brodzica, $n=2$

Phase Bocheniec, $n=5$

Phase Koszyce 3, n=5
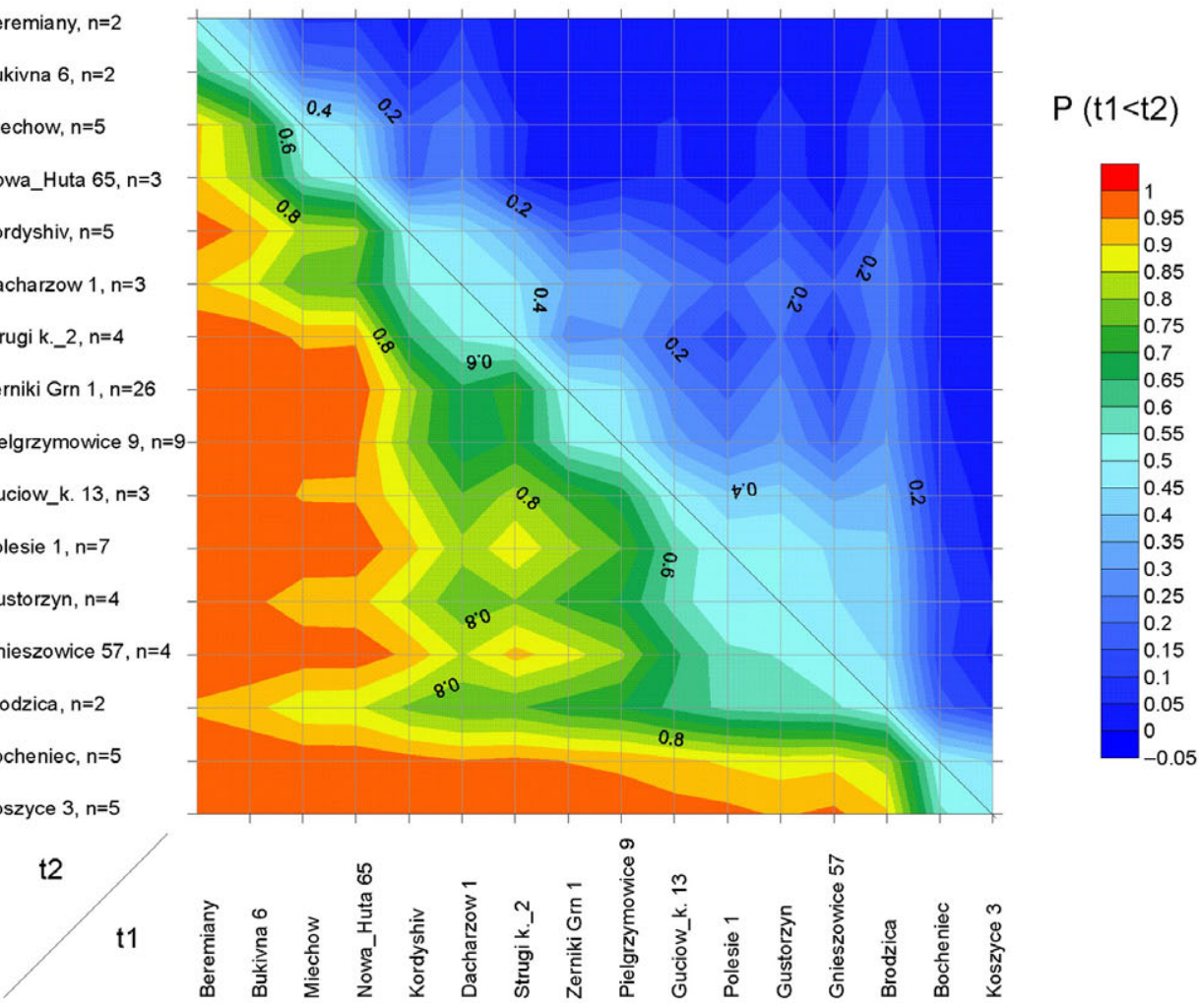

Figure 5 Upper part: older (red) and younger (green) boundaries of phases of using the analyzed burial grounds. The cemeteries in Dubeczno and Kazimierzów (dated by single samples only) were not taken into account. Lower part: matrix of probability showing chronological order of the older boundaries. (Please see electronic version for color figures.) 
finally in the Greater Poland-Kuyavian Lowland (Strugi, Gustorzyn) and central Poland (Polesie). In general, it seems that the idea of collective burials spread from the southeast to the northwest. This ritual custom was long-lasting in the Lesser Poland Upland (Miechów-Koszyce). It was simultaneously observed among barrow and "flat" cemeteries with no major chronological differences between cremated (in situ cremation in mortuary houses found inside barrows) and inhumation burials (cf. Makarowicz 2010a; Makarowicz et al. 2018).

\section{Żerniki Górne, Lesser Poland-Case Study}

Site 1 in Żerniki Górne (Figure 1:8) is located in the western part of Lesser Poland and is the largest cemetery of the TCC (Kempisty 1978: 34; Włodarczak 1998; Makarowicz 2010a). The excavated features included: stone circles, graves, mound, burnt layers and ceramic concentrations (Figure 6). In total, 15 collective graves were found with a minimum of 173 buried individuals. The graves were not distributed in a regular fashion, with the distance between them measuring from several centimeters to a few meters. The majority of them were found in the eastern part of the necropolis and were oriented along a N-S (NE-SW) axis, while in the southern and southwestern part of the cemetery they were oriented along a W-E axis (grave 62 shows a slight deviation to the southwestern direction). In the central part of the barrow there was a modern pit, which might have destroyed the assumed central burial. Graves had different sizes with areas measuring from $0.6 \mathrm{~m}^{2}$ (grave 5) to $8 \mathrm{~m}^{2}$ (grave 69) and volumes of $0.7 \mathrm{~m}^{3}$ (grave 3) to $8.1 \mathrm{~m}^{3}$ (grave 71).

Several spatio-temporal models have been constructed for the cemetery, including stratigraphic observations and the distributions of material culture (Kempisty 1978: 330-332; Włodarczak 1998: 173f.; Górski 2007: 25f.; Makarowicz 2010a: 221f.). The common thread of these models is the non-contemporaneity of the graves and non-grave features (stone circles, pits, burnt layers). The unresolved issue is the stratigraphic relationship between the barrow and some graves. Six spatial units were distinguished for the cemetery (Włodarczak 1998: 173; Makarowicz 2010a: 221f.), possibly linked to the different formation stages. They include (1) burnt layers, stone circles and pits 1, 2, 4, (2) graves 10, 12, 54, 62, and 86 (located to the south of the circles and oriented along the W-E axis), (3) graves 69, 71, 98, 99 as well as pits 5 and 123a (located to the east of the circles and oriented along the N-S), (4) graves $72,73,102,117$ and pit 3 (oriented similarly to group 4), (5) graves 3 and 5 dug into the mound, with a W-E orientation, and (6) the mound covering the stone circles and pits 1, 2, 3. The entire area measures ca. $650 \mathrm{~m}^{2}$.

Several observations can be made on the basis of the model outlined above. The cemetery, or rather sanctuary-cemetery, was successively expanded over the course of several generations. In the center of the necropolis-perhaps as a result of ritual activities-was an extensive but shallow burnt layer (ritual clearance of the surface?). The first stone circles constructed were I, II and III, along with some of the pits. The graves were not built simultaneously, as shown by the stratigraphic relations between them. For the majority of them there is no possibility of establishing a stratigraphic relationship with the barrow (Kempisty 1978: 331f.; Włodarczak 1998: 174). It seems plausible that the extent of the mound restricted the area available for construction of graves and affected their orientation, which allows the assumption that the majority of graves were dug after the construction of the mound (Górski 2007: 25). Thus, the barrow construction did not serve as a final stage of the cemetery. Even the mound itself was subsequently used, as shown by graves 3 and 5 (Kempisty 1978: 332). 


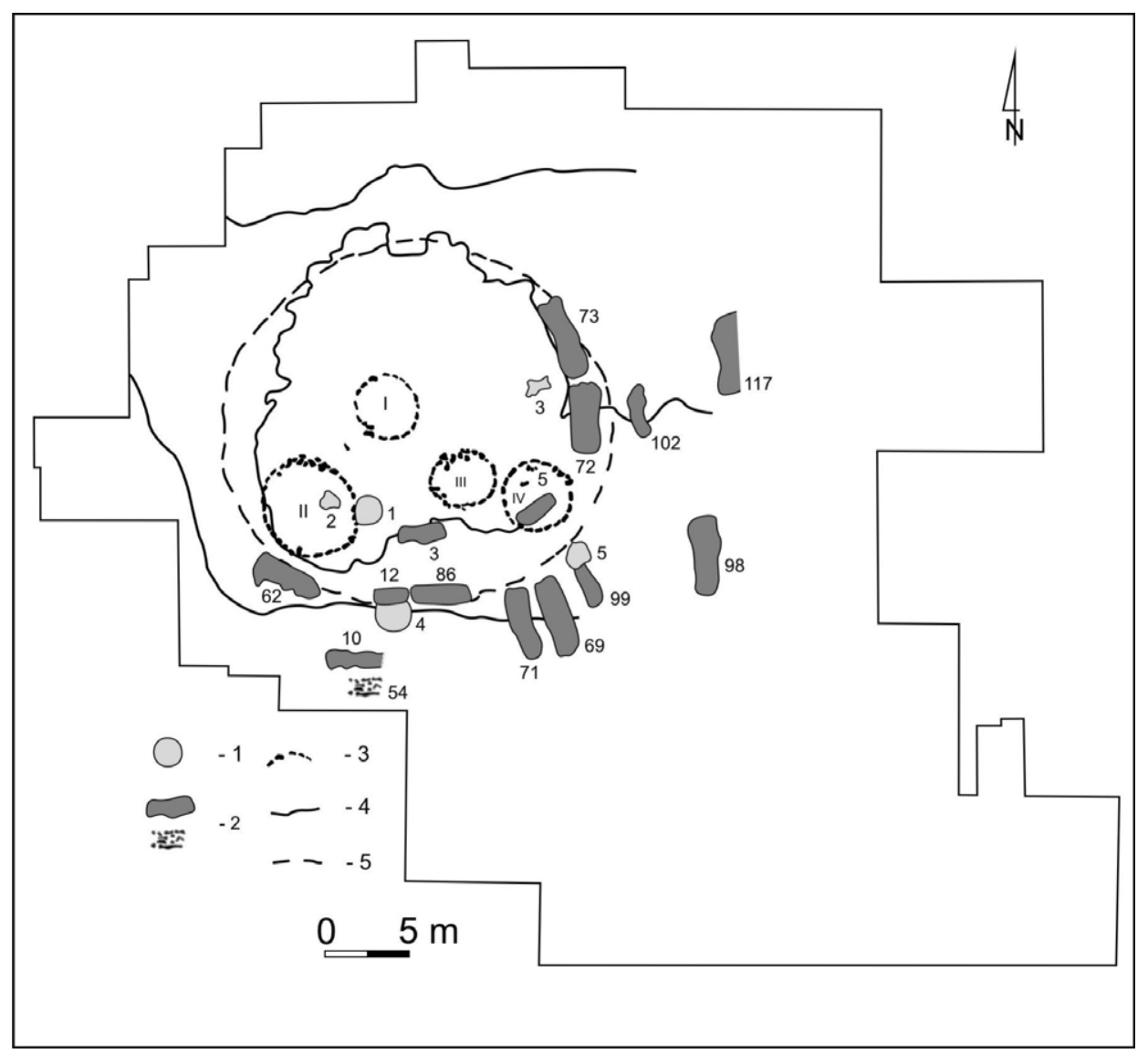

Figure 6 Layout of the cemetery in Żerniki Górne, site 1. 1—pit, 2—grave, 3—stone circle, 4—contemporary mound range, 5-primary mound range (Makarowicz 2010a).

The Żerniki Górne cemetery is characterized by a relatively large number of ${ }^{14} \mathrm{C}$ determinations, with 26 dates originating from 14 collective graves (grave 102 was not dated due to the poor bone preservation). One to six individuals were dated for every sampled grave (Table 1). The investigation of the temporal relationship of graves followed the methodology established for the analysis of cemeteries. However, sets of dates from one grave were Combined, assuming that all humans in the grave died roughly at the same time (Figure 7).

The modeled probability distributions show that burials in individual graves were occurring in different time periods (Figure 8, upper). Like for the analysis of the cemeteries, temporal relations between the use of particular graves were presented in a probability matrix, where every element " $\mathrm{P}\left(\mathrm{t}_{1}<\mathrm{t}_{2}\right)$ " shows the probability that grave " 1 " is older than grave " 2 " (Figure 8, lower).

The results of the Bayesian modeling allow testing of the hypotheses laid out above; namely, they allow the specification of the absolute chronology of the Żerniki Górne cemetery, especially the construction sequence of graves, their duration and the duration of grave groups. The probability distribution indicates that the necropolis was used for ca. 150-240 


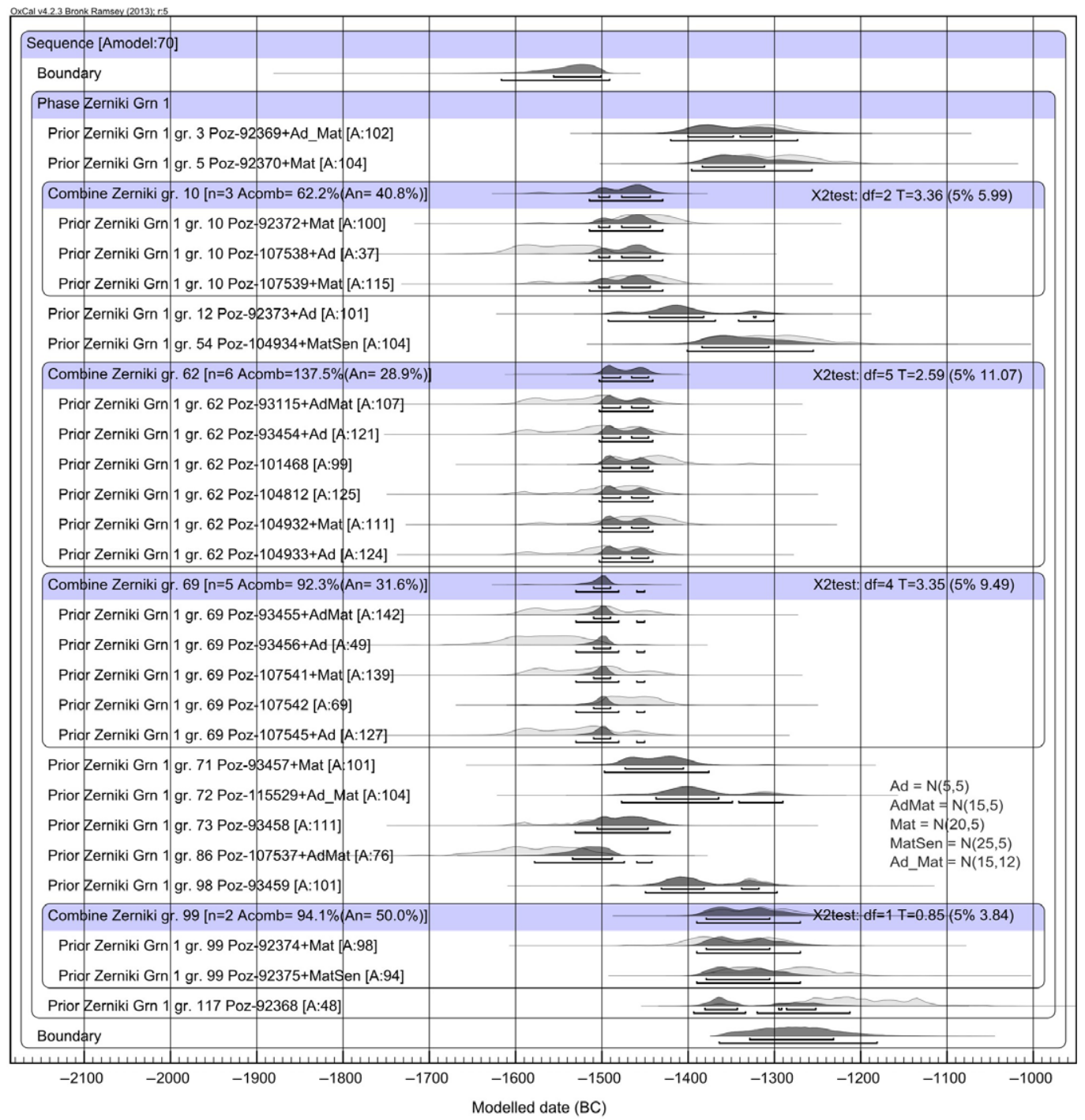

Figure 7 Bayesian chronological model of ${ }^{14} \mathrm{C}$ dates of bones from Żerniki Górne cemetery. For graves 10, 62, 69 and 99 , consistence of dates of different individuals in a grave was tested by $\chi^{2}$ statistics.

$(68.2 \%)$ or $140-310(95.4 \%)$ years, i.e., approximately a maximum of 12 generations (Figure 8, see also the Span displayed in Figure 4b). Based on these results, it appears that burials started in the southern part of the cemetery (graves $86,69,62,10,71,12$ ). The precise or standardized orientation of graves does not appear to have been significant during this process. Later on, graves were established in the eastern part of the cemetery (graves 72, 98 and then 117), although one of them, grave (73) in the northeastern part might have been established earlier than other burials from the southern concentration. The latest graves were established in the southern part (graves 54 and 99) and in the mid-southern area of the cemetery (graves 3 and 5 dug into the burial mound) It is noteworthy that many graves were used synchronously or partly synchronously (Figure 8, upper part). This could indicate the contemporaneous burial of individuals as well as groups, directly after their 


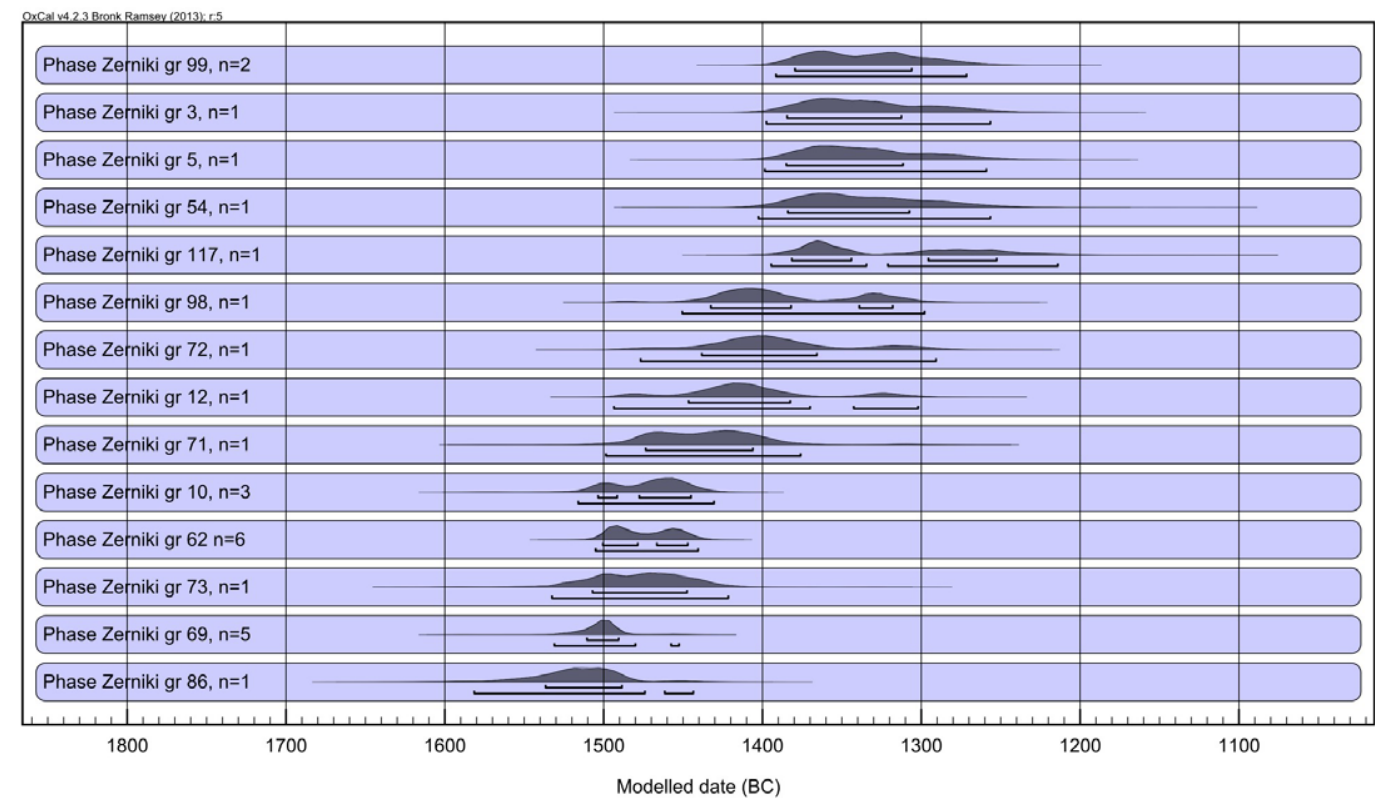

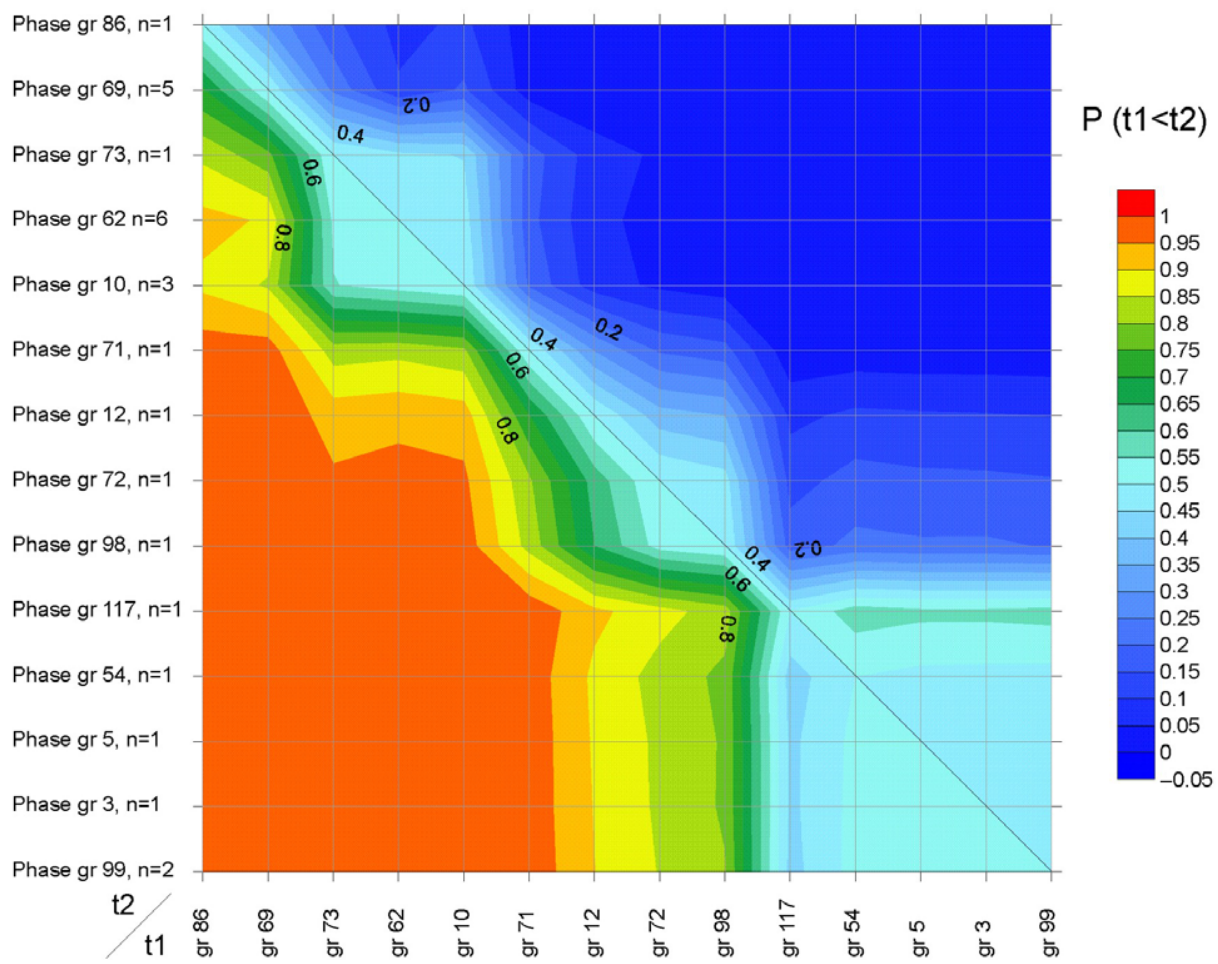

Figure 8 Upper part: modeled probability distributions of dates from the analyzed collective burials in Żerniki Górne. Lower part: matrix of probability showing chronological order of the described graves (lower part). 
death or excarnation (Makarowicz 2019), in graves located in different parts of the cemetery (see Figures 6 and 8, upper part).

Based on ancient mtDNA studies, the relationship between certain individuals within collective graves can be linked to matrilineal descent (Juras et al. 2020), though the nDNA analysis is still in progress. This suggests that the formation of the cemetery was a consequence of long-term, continued use by different family members and most likely distinct lineages/kinships (Makarowicz 2010a: 293f.). Such groups used specific graves, sometimes for a relatively long time and often in a synchronous way (Figure 8, upper part).

The absolute chronology does not indicate any relationship between the barrow and particular graves. It appears that the barrow covered only the stone circles and pits, as well as delimited the space for grave construction to the south and east (apart from graves 3 and 5 which were dug into the mound). Such a sequence of ritual practices: barrow construction followed by a formation of surrounding flat graves, is a common scenario for spatial development of cemeteries in the Early and Middle Bronze Age in Central-Eastern Europe and also among the TCC (e.g., Górski et al. 2011, 2012).

\section{Case Study of the Selected Collective Burial}

In order to investigate the overall duration of use of individual collective graves, the burying sequence in grave 669 from Pielgrzymowice was selected. This selection was primarily based on the availability of dating for all of the individuals buried in the grave.

Within the Pielgrzymowice settlement, a few single and collective graves were exposed, inside of which burials of males and females were documented. The individuals were buried in both anatomic and non-anatomic order. The ${ }^{14} \mathrm{C}$ dates suggest that the dead were placed there continuously for a long time period.

Grave 669 was a circular pit measuring $150 \mathrm{~cm}$ in diameter with a trapezoidal cross-section. At a depth of $100 \mathrm{~cm}$ from the level of discovery, a collective inhumation was exposed in which the articulated bones of six overlapping individuals were found (Figure 9). One individual was lying extended in a supine position. The remaining five individuals had been placed on their right or left side, with their legs pulled up to varying degrees. The bone material was found directly above the bottom of the pit. The fill contained only a few pottery sherds with no burial goods. The oldest ${ }^{14} \mathrm{C}$ determination was $3180 \pm 35$; the youngest $3030 \pm 35$ BP (Table 1).

The relatively wide time span indicates that not all individuals buried inside died at the same time (combining these dates brings the $C h i^{2}$ of 11.96 , that exceeds the $5 \%$ critical value for $\mathrm{df}=5$ [11.10]). In order to examine this observation, all of the dates were grouped into a single-phase (Figure 10, upper part), and the probability distribution of the resulting span was calculated ("Span", Figure 10, bottom left). Additionally, a probability matrix for every element " $\mathrm{P}\left(\mathrm{t}_{1}<\mathrm{t}_{2}\right)$ " shows the probability that a randomly selected burial from grave " 1 " is older than the randomly selected burial from grave "2" (Figure 10, bottom right).

The Bayesian modeling shows - even assuming all dates are representing a single phase - that individuals were not buried within a short time span ( $1 \sigma: 34-169 \mathrm{yr}$, Figure 10, bottom left). In addition, the calendar date of the sample Poz-107544, with a probability of 0.9 , is older than samples Poz-104944 and Poz-101475. This indicates that some of the individuals buried in 


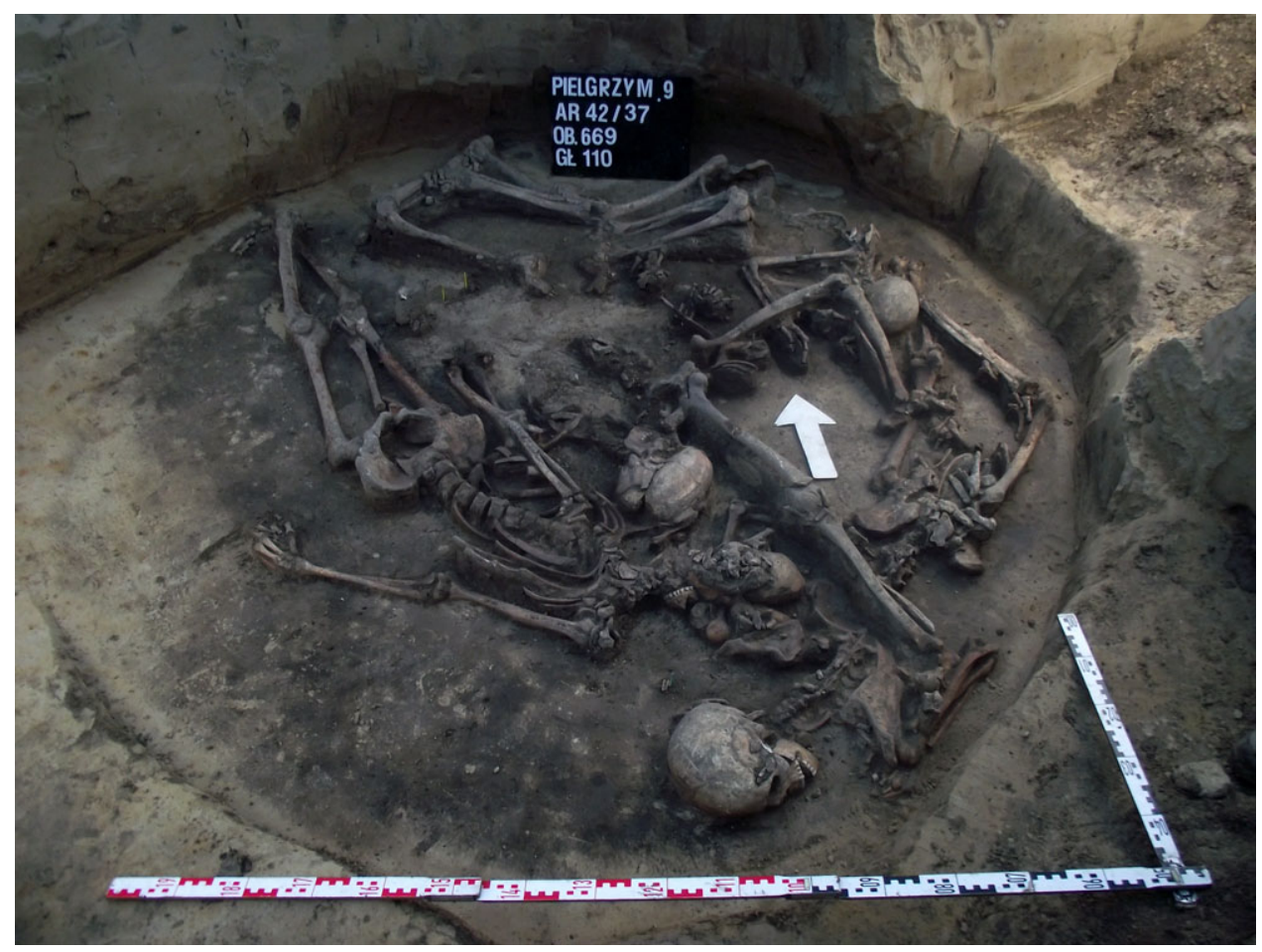

Figure 9 Pielgrzymowice. Collective burial (grave 669). Photo: A. Lasota-Kuś.

grave 669 died at different times, a pattern supported by archaeological data (spatial distribution of the remains and stratigraphic observations) from other collective graves found in different cemeteries. In general, burials of additional individuals or groups required the displacement of the previously deceased. Only in some instance would the bodies be deposited on the previously laid remains (Makarowicz 2010a: 244-253; Szczepanek 2013).

However, this chronological observation is not related to the date of burial as much as to the date of death of the analyzed individuals. From an archaeological standpoint, there is evidence of gathering of the deceased in other areas prior to the final burial or temporary burial in special structures, e.g., mortuary houses with good accessibility (Górski 2018; Makarowicz 2019). In terms of the Pielgrzymowice collective burial, the deceased were buried on the same level, i.e., the bottom of the pit, which confirms the hypothesis regarding the contemporaneous burial of individuals who had died at a different time.

Similar indications that individuals buried in one grave died at different times (over a time span of several decades or even up to 200 years) concern some other collective graves, e.g., Polesie, grave 1182; Gustorzyn, grave 5; and Bocheniec, grave 118. Alternatively, the burials found in the barrows in Strugi and Guciów suggest that the individuals died within a short time period or even contemporaneously, which led to a relatively fast burial of multiple individuals (Table 1; Figure 4).

The analysis above suggests that some collective graves were used for a relatively long period of time, some of them even for 150-250 years. However, the burial rhythm remains unknown. 

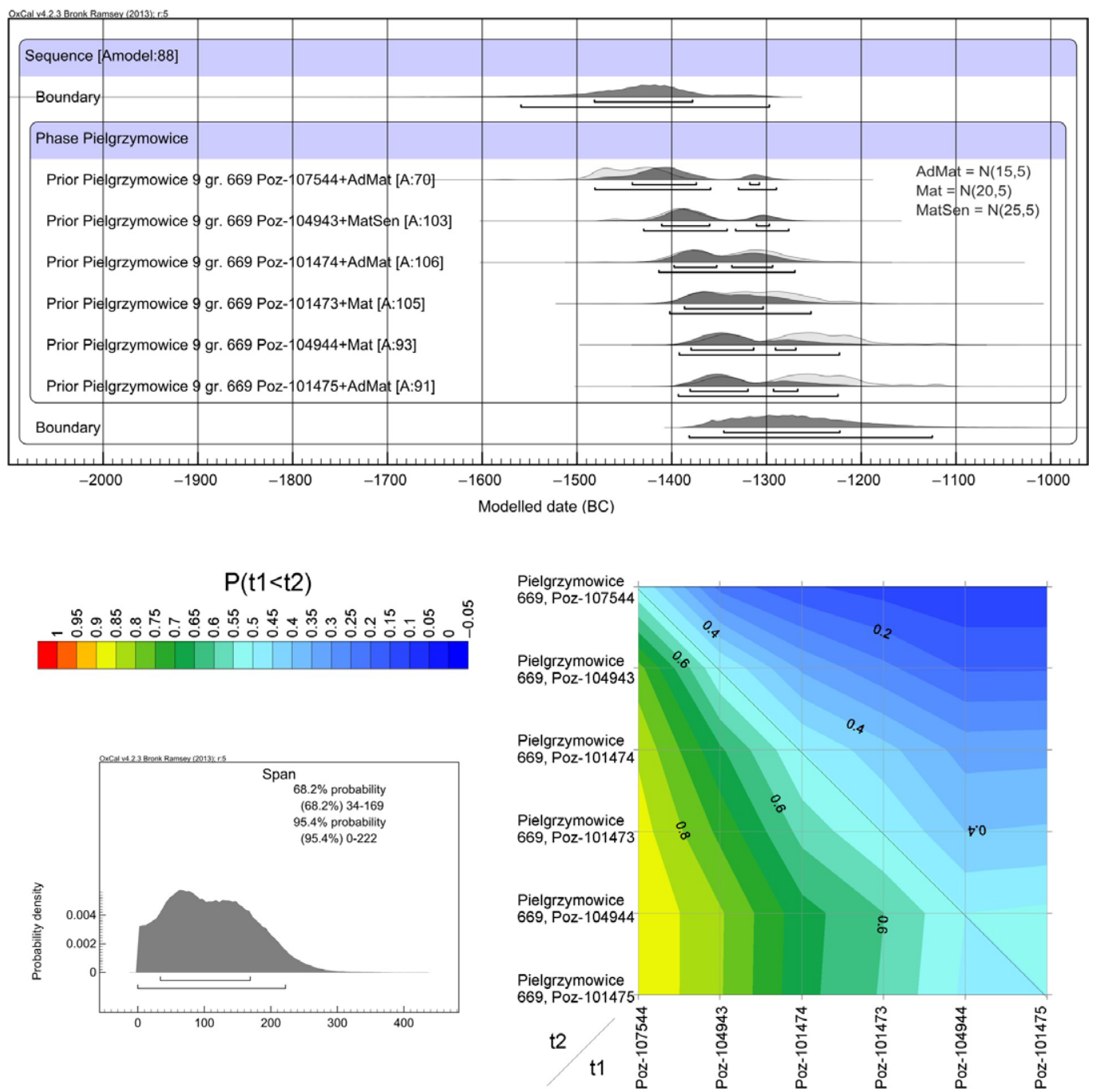

Figure 10 Upper part: Bayesian model of the ${ }^{14} \mathrm{C}$ dates from the individuals buried in grave 669 in Pielgrzymowice. Bottom left: probability distribution of the death time span of the analyzed individuals. Bottom right: probability matrix of the temporal ordering of the analyzed individuals.

People died at different times, but after their death they might have been kept in an ossuary until a larger number of deceased accumulated (Górski, Tyniec 2018; Makarowicz 2019). Perhaps the burial ritual was linked to major social events, e.g., the termination of a lineage or the death of the final family member. Until excarnation, the corpses might have been deposited elsewhere, the duration of which is related to different climatic conditions and could last from several months to a few years (Makarowicz 2019). Such observationslinked to the non-continuous use of collective graves-are increasingly frequent after the incorporation of Bayesian modeling for large datasets originating from Neolithic megalithic graves, where chambers were re-opened in order to bury additional individuals or groups (e.g., Aranda Jiménez, Lozano Medina 2014; Aranda Jiménez et al. 2018; Salazar-García 
et al. 2016; Steuri et al. 2019). The burial rite of the TCC communities, especially collective burials, partial burials, dismemberment, and non-anatomic positioning of the individuals shows links to the preceding megalithic practices (e.g., Tomé et al. 2014), especially behavior patterns documented among the Late Neolithic Globular Amphorae Culture (Szmyt 1999; Makarowicz 2010a; 2010b; Nowaczyk et al. 2017).

\section{CONCLUSIONS}

The results of the investigation can be summarized in the following points:

1. The collective burial of individuals was typical during the entire duration of the TCC from the Early/Classical to the Late phase between 1830-1690 (95.4\%) and 1320-1160 (95.4\%) BC, i.e., ca. 400-640 (95.4\%) years $=16-25$ generations.

2. Collective burials were especially widespread in the upland (southern) part of the TCC area. The modeled ${ }^{14} \mathrm{C}$ ages suggest that the phenomenon of such burials spread relatively fast and roughly from the SE to the NW.

3. The oldest graves with multiple individuals were found in Beremiany (flat grave) and Bukivna (barrow grave) in the Upper Dniester basin, Dubeczno in the Western Polissia (barrow grave) and Nowa Huta-Mogiła in the Lesser Poland Upland (flat grave). In general, the collective burials appeared simultaneously in under-barrow and flat graves. Both cremation and inhumation were present in mass burials at the same time.

4. Bayesian modeling of the ${ }^{14} \mathrm{C}$ dates from the Żerniki Górne cemetery in the Lesser Poland Upland allowed estimating the duration of the largest TCC cemetery as 140-310 $(95.4 \%)$ years.

5. In some collective burials, individuals were buried over an extensive period of time (in extreme cases up to 8-10 generations), while in others the burials comprised of individuals both dying and being interred in graves within a much shorter time span.

6. The death of an individual did not necessarily result in an immediate burial in a mass grave. Some deceased (e.g., Pielgrzymowice, grave 669) were buried in groups after a certain time, similarly to the practices observed in megalithic traditions. Their remains were awaiting a final burial in a different area (e.g., an ossuary) until excarnation, accumulation of a larger number of deceased or termination of a family or lineage.

7. Some collective graves found on larger cemeteries were used contemporaneously probably by different social groups (families, lineages?) of the TCC community.

\section{ACKNOWLEDGMENTS}

This work was supported by the Polish National Science Center (NSC) grant No. 2015/17/B/ HS3/00114) lead by Przemysław Makarowicz. Janusz Czebreszuk was supported by NSC grant No 2014/15/G/HS3/04720, Marek Nowak was supported by NSC grant No 2016/23/B/HS3/ 00387, Małgorzata Marcinkowska-Swojak and Marek Figlerowicz were supported by NSC grant No. 2014/12/W/NZ2/00466. We would like to thank Robert Staniuk, ChristianAlbrechts-Universität zu Kiel, and Sarah Martini, Yale University, for linguistic corrections and their careful comments on the original manuscript. 


\section{REFERENCES}

Aranda Jiménez G, Lozano Medina A. 2014. The chronology of megalithic funerary practices: a Bayesian approach to Grave 11 at El Barranquete necropolis (Almería, Spain). Journal of Archaeological Science 50:369-382.

Aranda Jiménez G, Lozano Medina A, Sánchez Romero M, Díaz-Zorita Bonilla M. 2018. Chronology of megalithic funerary practices in southeastern Iberia: the necropolis of Panoria (Granada, Spain). Radiocarbon 60(1):1-19.

Banasiewicz-Szykuła E, Gołub I, Koman W, Stachyra A, Wetoszka B. 2008. Sprawozdanie z działalności $\mathrm{W}$ zakresie ochrony zabytków archeologicznych na terenie woj. lubelskiego w 2007 roku. Wiadomości Konserwatorskie Województwa Lubelskiego 10:25-69.

Barta P, Štolc S. 2007. HBCO correction: its impact on archaeological absolute dating. Radiocarbon 49(2):465-472.

Bátora J. 1999. Gräber mit Totenhäusen auf frühbronzezeitlichen Gräberfeldern in der Slovakei (Beitrag zu Kultur verbindungen zwischen Mittel-, West- und Osteuropa). Praehistorische Zeitschrift 74:1-57.

Braudel F, Arnaldez R, Aymard M, Coarelli F, Duby G, Guademet J, Solinas P. 1994. Morze Śródziemne. Przestrzeń i historia. Ludzie i dziedzictwo. Warszawa: Oficyna Wydawnicza Volumen. Nowa Marianna.

Brock F, Higham T, Ditchfield P, Bronk Ramsey C. 2010. Current pretreatment methods for AMS radiocarbon dating at the Oxford Radiocarbon Accelerator Unit (ORAU). Radiocarbon 52(1): 103-112.

Bourgeois Q, Kroon E. 2017. The impact of male burials on the construction of Corded Ware identity: Reconstructing networks of information in the 3rd millennium BC. PLoS ONE 12(10): e0185971. doi: 10.1371/journal. pone. 0185971 .

Bronk Ramsey C. 1995. Radiocarbon calibration and analysis of stratigraphy: the OxCal program. Radiocarbon 37(2):425-430.

Bronk Ramsey C. 2009. Bayesian analysis of radiocarbon dates. Radiocarbon 51(1):337-360.

Bronk Ramsey C, Higham T, Bowles A, Hedges REM. 2004. Improvements to the pretreatment of bone at Oxford. Radiocarbon 46(1):155-163.

Bronk Ramsey C, Lee S. 2013. Recent and planned developments of the program OxCal. Radiocarbon 55(2):720-730.

Cook GT, Bonsall C, Hedges REM, McSweeney K, Boronean V, Pettitt P. 2001. A freshwater diet-derived ${ }^{14} \mathrm{C}$ reservoir effect at the Stone Age sites in the Iron Gates Gorge. Radiocarbon 43(2A):453-460.

Cunliffe B. 2011. Europe between the oceans. themes and variations: 9000 BC-AD 1000. New Haven and London: Yale University Press.
Czebreszuk J. 2008. Corded ware from East to West. In: Bogucki P, Crabtree PJ, editors. Ancient Europe 8000 B.C.-A.D. 1000. Encyclopedia of the barbarian world. Vol. I. The Mesolithic to Copper Age (c. 8000-2000 B.C.). New York: Charles Scribner's Sons. p. 467-475.

Florek M, Taras H. 2003. Dacharzów. Cmentarzysko kultury trzcinieckiej. Lublin: Wydawnictwo UMCS.

Furholt M. 2014. Upending a 'totality': re-evaluating corded ware variability in Late Neolithic Europe. Proceedings of the Prehistoric Society 80:67-86.

García Sanjuán L, Vargas Jiménez JM, Cáceres Puro LM, Costa Caramé ME, Díaz-Guardamino U, Díaz-Zorita Bonilla M., Fernández Flores Á, Hurtado Pérez V, López Aldana PM, Méndez Izquierdo E, Pajuelo Pando A, Rodríguez Vidal J, Wheatley D, Bronk Ramsey C, DelgadoHuertas A, Dunbar E, Mora González A, Bayliss A, Beavan N, Hamilton D, and Whittle A. 2018. Assembling the dead, gathering the living: radiocarbon dating and Bayesian modelling for Copper Age Valencina de la Concepción (Seville, Spain). Journal of World Prehistory 31(2):179-313.

Geyh M. 2001. Bomb radiocarbon dating of animal tissues and hair. Radiocarbon 43(2):723-730.

Goslar T, Czernik J, Goslar E. 2004. Low-Energy ${ }^{14} \mathrm{C}$ AMS in Poznań Radiocarbon Laboratory, Poland. Nuclear Instruments and Methods in Physics Research B 223(4):5-11.

Goslar T, Jankowski M, Kośko A, Lityńska-Zając M, Włodarczak P, Żurkiewicz D. 2017. Builders and users of ritual centres, Yampil Barrow Complex: studies of diet based on stable nitrogen and carbon isotope composition. Baltic-Pontic Studies 22:91-125.

Górski J. 2007. Chronologia kultury trzcinieckiej na lessach Niecki Nidziańskiej. Kraków: Biblioteka Muzeum Archeologicznego w Krakowie.

Górski J. 2017. The Trzciniec culture. On the periphery of Bronze Age civilization (1800-1100 BC). In: Urbańczyk P, editor. The Past Societies. Polish lands from the first evidence of human presence to the Early Middle Ages, Warszawa, vol. 3 (2000-500 BC). Warszawa: Institute of Archaeology and Ethnology Polish Academy of Sciences. p. 87-126.

Górski J, Makarowicz P. 2012. Nowe datowania radiowęglowe kurhanów i grobów beznasypowych trzcinieckiego kręgu kulturowego z Małopolski i Wielkopolski. In: Blajer W, editor. Peregrinationes archaeologicae in Asia et Europa Joanni Chochorowski dedicatae. Kraków: Instytut Archeologii Uniwersytetu Rzeszowskiego, Fundacja Uniwersytetu Rzeszowskiego. p. 289-298.

Górski J, Makarowicz P, Wawrusiewicz A. 2011. Osady i cmentarzyska społeczności trzcinieckiego kręgu kulturowego w Polesiu, stanowisko 1, 
województwo łódzkie. Łódź: Instytut Archeologii Uniwersytetu Łódzkiego, Fundacja Uniwersytetu Łódzkiego.

Górski J, Makarowicz P, Wawrusiewicz A. 2012. Spatial development of the settlement complex affiliated to the Trzciniec cultural circle at site 1 in Polesie in Central Poland. Sprawozdania Archeologiczne 65:195-224.

Górski J, Tyniec A. 2018. Fenomen miejsca. Nekropola kurhanowa z neolitu, epoki brązu i wczesnego średniowiecza w Guciowie, pow. zamojski. Kraków: Biblioteka Muzeum Archeologicznego w Krakowie.

Grygiel R. 1987. Z badań nad kulturą trzciniecką w rejonie Brześcia Kujawskiego. In: Kultura trzciniecka w Polsce. Kraków: PTAiM. p. 73-88.

Harding AF. 2000. European societies in the Bronze Age. Cambridge: Cambridge University Press.

Heyd V. 2013. Europe 2500 to 2200 BC: Between expiring ideologies and emerging complexity. In: Fokkens H, Harding A, editors. The Oxford Handbook of the European Bronze Age. Oxford: Oxford University Press. p. 47-67.

Ilchyshyn V. 2016. Komarivskiy gorizont bagatosharovogo kurgannogo mogilnika Kordishiv VIII na Shumshchini. Materiali i doslidzhennya $\mathrm{z}$ arkheologii Prikarpattya i Volini 20:259-272. In Ukrainian.

Juras A, Makarowicz P, Chyleński M, Ehler E, Malmström H, Krzewińska M, Pospieszny $Ł$, Górski J, Taras H, Szczepanek A, Polańska M, Włodarczak P, Szyca A, Lasota-Kuś A, Wójcik I, Jakobsson M, Dabert M. 2020. Mitochondrial genomes from Bronze Age Poland reveal genetic continuity from the Late Neolithic and additional gene flow from the steppe. American Journal of Physical Anthropology 172(2):176-188. doi: 10. 1002/ajpa.24057.

Kadrow S. 2001. U progu nowej epoki. Gospodarka i społeczeństwo wczesnego okresu epoki brązu w Europie Środkowej. Kraków: Instytut Archeologii i Etnologii Polskiej Akademii Nauk.

Kempisty A. 1978. Schyłek neolitu i początek epoki brązu na Wyżynie Małopolskiej w świetle badań nad kopcami. Warszawa: Wydawnictwa Uniwersytetu Warszawskiego.

Kłosińska E. 1987. Zagadnienie cmentarzysk kurhanowych kultury trzcinieckiej. In: Kultura trzciniecka w Polsce. Kraków: PTAiM. p. 35-55.

Kłosińska E, Taras H, Sadowski S. 2010. Doslidzhennya pamiatok dobi bronzi ta rannogo zaliza v 2000-2007 rokah u seredniy chastini skhidnoy Polshchi. Materiali i doslidzhennya z Arkheologii Prikarpattya i Volini 14:243-257. In Ukrainian.

Kośko A, Klochko V. 1998. "Trzciniec"-borderland of Early Bronze civilizations of Eastern and Western Europe? Baltic-Pontic Studies 6:190-202.

Kristiansen K. 1998. Europe before history. Cambridge: Cambridge University Press. 505 p.
Lanting JN, van der Plicht J. 2001. Dating of cremated bones. Radiocarbon 43(2A):249-254.

Longin R. 1971. New method of collagen extraction for radiocarbon dating. Nature 230:241-242.

Makarowicz P. 2010a. Trzciniecki krąg kulturowywspólnota pogranicza Wschodu i Zachodu Europy, Archaeologia Bimaris. Monografie, tom 3. Poznań: Wydawnictwo Poznańskie.

Makarowicz P. 2010b. Geneza pochówków zbiorowych w trzcinieckim kręgu kulturowym. In: Czopek S, Kadrow S, editors. Mente et rutro. Studia archaeologica Johanni Machnik viro doctissimo octogesimo vitae anno ab amicis, collegis et discipulis oblate. Rzeszów: Instytut Archeologii Uniwersytetu Rzeszowskiego, Fundacja Uniwersytetu Rzeszowskiego. p. 379-398.

Makarowicz P. 2019. Dom zmarłych z kurhanu 6 w Bukivnej. Z badań nad architektura podkurhanową $\mathrm{w}$ górnodniestrzańskiej enklawie kultury komarowskiej. In: Szmyt M, Chachlikowski P, Czebreszuk J, Ignaczak M, Makarowicz P, editors. Vir Bimaris. Od kujawskiego matecznika do stepów nadczarnomorskich. Studia z dziejów międzymorza bałtycko-pontyjskiego ofiarowane Profesorowi Aleksandrowi Kośko. Archaeologia Bimaris. Discussion, vol. 5, Poznań: Instytut Archeologii UAM. p. 737-753.

Makarowicz P, Goslar T, Niebieszczański J, Cwaliński M, Kochkin IT, Romaniszyn J, Lysenko SD, Ważny T. 2018. Middle Bronze Age societies and barrow line chronology. A case study from the Bukivna 'necropolis', Upper Dniester Basin, Ukraine. Journal of Archaeological Science 95:40-51.

Matoga A. 1985. Wstępne wyniki badań na cmentarzysku z III-V okresu epoki brązu w Bocheńcu, woj. Kielce. Sprawozdania Archeologiczne 27:81-109.

Nowaczyk S, Pospieszny Ł, Sobkowiak-Tabaka I, editors. 2017. Megalityczny grobowiec kultury amfor kulistych z Kierzkowa na Pałukach. Milczący świadek kultu przodków $\mathrm{Z}$ epoki kamienia. Biskupin: Muzeum Archeologiczne w Biskupinie. Biskupin: Biskupińskie Prace Archeologiczne 12.

Olsen J, Heinemeier J, Lübke H, Lüth F, Terberger T. 2010. Dietary habits and freshwater reservoir effects in bones from a Neolithic ME Germany cemetery. Radiocarbon 52(2-3):635-644.

Pospieszny Ł, Makarowicz P, Lewis J, Górski J, Taras H, Włodarczak P, Szczepanek A, Ilchyshyn V, Jagodinska MO, Czebreszuk J, Muzolf P, Nowak M, Polańska M, Juras A, Chyleński M, Wójcik I, Lasota-Kuś A, Romaniszyn J, Tunia K, Przybyła MM, Grygiel R, Matoga A, Goslar $\mathrm{T}$. In press. Isotopic evidence of millet consumption in the Middle Bronze Age of EastCentral Europe. Journal of Archaeological Science. 
Reimer PJ, Bard E, Bayliss A, Beck WJ, Blackwell PG, Bronk-Ramsey C, Buck CE, Cheng $\mathrm{H}$, Edwards RL, Friedrich N, Grootes PM, Guilderson TP, Hafidason H, Hajdas I, Hattè C, Heaton TJ, Hoffmann DL, Hogg AG, Hughen KA, Kaiser KF, Kromer B, Manning SV, Niu M, Reimer RW, Richards DA, Scott EM, Southon JR, Staff RA, Turney SM, Van der Plicht J. 2013. IntCal13 and Marine13 Radiocarbon age calibration curves 0-50,000 years cal BP. Radiocarbon 55(4):1869-1887.

Reitsema LJ, Crews DE, Polcyn M. 2010. Preliminary evidence for medieval Polish diet from carbon and nitrogen stable isotopes. Journal of Archaeological Science 37:1413-1423.

Romaniszyn J, Gwizdała M, Makarowicz P. 2016. Grób $\mathrm{z}$ Beremian nad Dniestrem - rewizja wyników badań z XIX wieku. Ze studiów nad grupa białopotocką kultury komarowskiej, Materiały Archeologiczne 41:7-21.

Salazar-García DC, García-Puchol O, de MiguelIbáñez MP, Talamo S. 2016. Earliest evidence of Neolithic collective burials from eastern Iberia: radiocarbon dating at the archaeological site of Les Llometes (Alicante, Spain). Radiocarbon 58(3):679-692.

Snoeck C, Brock F, Schulting RJ. 2014. Carbon exchanges between bone apatite and fuels during cremation: impact on radiocarbon dates. Radiocarbon 56(2):591-602.

Stuiver M, Polach HA. 1977. Discussion: reporting of ${ }^{14} \mathrm{C}$ data. Radiocarbon 19(3):355-363.

Szczepanek A. 2013. Archeotanatologia pochówków zbiorowych od pradziejów po czasy współczesne. Rzeszów: Instytut Archeologii Uniwersytetu Rzeszowskiego, Fundacja Uniwersytetu Rzeszowskiego.

Steuri N, Siebke I, Furtwängler A, Sönke S, Krause J, Lösh S, Hafner A. 2019. Multiple radiocarbon dating of human remains: clarifying the chronology and sequences of burials in the Late
Neolithic dolmen of Oberbipp (Switzerland). Radiocarbon 61(6):1697-1709.

Szmyt M. 1999. Between West and East. People of the Globular Amphora Culture in Eastern Europe: 2950-2350 BC. Baltic-Pontic Studies 8.

Taras H. 1995. Kultura trzciniecka w międzyrzeczu Wisły, Bugu i Sanu, Lublin: Wydawnictwo UMCS.

Thomas M. 2008. Studien zu Chronologie und Totenritual der Otomani-Füzesabony Kultur. Bonn: Dr. Rudolf Habelt Verlag GmbH.

Tomé T, Díaz-Zorita Bonilla M, Silva AM, Cunha C, Boaventura R, editors. 2014. Current approaches to collective burials in the Late European prehistory. Oxford: Archaeopress Publishing Ltd.

van Klinken GJ. 1999. Bone collagen quality indicators for palaeodietary and radiocarbon measurements. Journal of Archaeological Science 26:687-695.

Vander Linden M. A 2013. Little bit of history repeating itself: theories on the Bell Beaker Phenomenon. In: Fokkens H, Harding A, editors. The Oxford handbook of the European Bronze Age. Oxford: Oxford University Press. p. 68-81.

Whittle A. 1996. Europe in the Neolithic. Cambridge: Cambridge University Press.

Włodarczak P. 1998. Groby kultury mierzanowickiej oraz kultury trzcinieckiej z Żernik Górnych. In: Kośko A, Czebreszuk J, editors. „Trzciniec”system kulturowy czy interkulturowy proces? Poznań: Wydawnictwo Poznańskie. p. 161-177.

Włodarczak P. 2017. Battle-Axes and beakers. The Final Eneolithic societies. In: Urbańczyk P, editor. Polish lands from the first evidence of human presence to the early Middle Ages, Vol 2. 5500-2000 BC. Warszawa: Institute of Archaeology and Ethnology Polish Academy of Sciences. p. 275-336.

Zich B. 1996. Studien zur regionalen und chronologischen Gliederung der nrdlichen Aunjetitzer Kultur, Vorgeschichtliche Forschungen, Band 20. Berlin-New York: Walter de Gruyter. 